\title{
Siyasal Kimlik, Hayat Tarzı ve Siyasal Tercih:Malatya Seçmeni Üzerine Bir Araştırma
}

\author{
Political Identity, Lifestyle and Political Choice: A Research on Malatya Voters
}

\author{
Adem DO $\breve{G} A N *$ \\ Hasan BATAR **
}

\section{$\ddot{O} Z$}

Siyasal kimlikler, bir yönüyle siyaset, diğer yönüyle kimlik oluşum süreci üzerinden oluşturulmaktadır. Siyasal kimlikler partiler üzerinden şekillenmekte, siyasi partiler üzerinden işlevsel hale gelmektedir. Siyasal kimlik ve siyasal parti arasındaki diyalektik ilişkinin yansımasını doğal olarak siyasal tercihte de görmek mümkündür. Bu çerçevede hayat tarzı da siyasi kimlik ve siyasi tercih bă̆lamında önemli bir olgudur. Hayat tarzl, bireylerin değerleri, ilgi alanları, sosyal ilişkileri, gündelik yaşam içerisindeki pratiklerini ve siyasal tercihlerini de kapsayan bir olguyu ifade etmektedir. Bireylerin hayat tarzları da gündelik yaşam pratikleri kadar çeşitli olaylara bakışlarını, siyasal kimliklerini ve siyasal tercihlerini de etkileyebilmektedir. Bu anlamda siyasal kimlik, hayat tarzl ve siyasal tercih bir birlerini etkileyebilen olgular olarak değerlendirilmektedir. Bu çalışmada siyasal kimlik, yaşam tarzı ve siyasal tercih olguları Malatya ilinde yapılan bir araştırma ile çeşitli değişkenler tarafindan analiz edilerek, bu olguların bir birleri ile ilişkileri de ortaya konulmaya çalışılmıştır. Alan araştırması yönteminin uygulandığı bu çalışmada veriler anket tekniği ile elde edilmiştir. Örneklem grubunu oluşturan 1531 katılımc ile yüz yüze görüşülerek elde edilen veriler analiz edilmiştir. Elde edilen bulgulara göre siyasal kimlik, hayat tarzı ve siyasal tercih bağlamında katılımcıların çeşitli konulara ilişkin bakış açıları arasında anlamlı ilişki vardır.

\section{ANAHTAR KELIMELER}

Ekonomik Kalkınma, Bölgesel Kalkınma, Alternatif Turizm, Beyşehir

\begin{abstract}
Political identities are formed through politics in one aspect and identity formation in the other. Political identities are shaped through parties and become functional through political parties. The reflection of the dialectical relationship between political identity and political party is naturally also seen in political choice. In this context, lifestyle is also an important phenomenon in terms of political identity and political choice. Lifestyle refers to a phenomenon that includes individuals' values, interests, social relations, practices and political preferences in daily life. Individuals' lifestyles can affect daily life practices as well as their views on various events, their political identities and their political preferences. In this sense, political identity, lifestyle and political choice are considered as inter-influential phenomena. In this study, political identity, lifestyle and political preference phenomena are analyzed by various variables in a research conducted in Malatya province and the relationship between these phenomena is also put forward. In this study in which field research method was applied, the data were obtained by questionnaire technique. A total of 1531 participants were interviewed face to face and the data were analyzed. According to the findings, there is a significant relationship between the participants' perspectives on various issues in the context of political identity, lifestyle and political choice.
\end{abstract}

\section{KEYWORDS}

Political Identity, Lifestyle, Political Choice

\begin{tabular}{|c|c|c|}
\hline & $\begin{array}{c}\text { Makale Geliş Tarihi / Submission Date } \\
02.07 .2019\end{array}$ & $\begin{array}{c}\text { Makale Kabul Tarihi / Date of Acceptance } \\
\text { 05.11.2019 }\end{array}$ \\
\hline Atıf & $\begin{array}{l}\text { Doğan, A. ve Batar, H. (2019). Siyasal } \\
\text { Selçuk Üniversitesi Sosyal Bilimler Me }\end{array}$ & $\begin{array}{l}\text { Siyasal Tercih:Malatya Seçmeni Üzerine Bir Araştırma. } \\
\text { isi, } 22 \text { (2), 931-949. }\end{array}$ \\
\hline
\end{tabular}

\footnotetext{
* Doç. Dr., Frrat Üniversitesi İletişim Fakültesi, ademdogan23@hotmail.com, ORCID: 0000-0003-0933-6072

*** Doktora Öğrencisi, Fırat Üniversitesi Sosyal Bilimler Enstitüsü, hasanbatar@gmail.com ORCID: 0000-0003-4245-0168
} 


\section{GİRIŞ}

Kimlik, Sokrates'in "Kendini tanı!"sından başlayarak, nice ustalardan geçip Freud'a gelinceye kadar felsefenin en öncelikli sorunu olmuştur (Maalouf, 15:2000) ve halen daha bu özelliğini devam ettirmektedir. Dolayısıyla kimlik tanımlaması kadar boyutlandırması da kolay olmayan bir kavramdır.

Kimlik, bir insanın sosyal çevre, din, kültür, aile, sosyal gruplar gibi çeşitli faktörlerin etkileşimi ile oluşmaktadır. Kişilerin toplumsal konumları ve üyesi oldukları çeşitli gruplar içerisindeki rolleri onların kimliklerini etkiler. Kimlik, rollere ilişkin anlamlara ek olarak davranış, beceri ve donanımları içerir.

Kimlik, insanın neyi nasıl yaptığı veya yapmadığı, kendini ve diğerini nasıl gördüğü ve değerlendirdiği; ilişkilerini nasıl düzenlediği ve yürüttügü̈, şimdiyle ilgili olarak ne yaptığı ve ne yapmadığı; sevileri, kaygıları, beklentileri, tercihlerinin neler olduğu, gelecekle ilgili umutları ve umutsuzlukları ile ilgilidir. Kimlik (ve kültür) insanın ne olduğunu, nasıl olduğunu ve neden olduğunu düşüncelerden ve yaptıkları ve yapmadıklarından geçerek kendine ve dışına anlatmasıyla belirir. Kimlik insanın ne olduğu, nasıl olduğu, kendine ve dünyasına bakışı ve kendiyle ve dışılla olan ilişkilerini düzenleyişinin doğasını anlatır (Erdoğan, 2006:2). Bu çerçevede Castelss'in (2006:12) ifadesiyle kimlik, insanların anlam ve tecrübe kaynă̆ıdır

Toplumsal ve bireysel anlam dünyamızın şekillenmesinde de belirleyici olan kimlik, bizim haricimizdeki insanların nazarındaki fotoğrafımız olarak ayırt edici özelliğimizin karşılığıdır. Sınırları genişledikçe kimlik algıları çeşitlenmekte, farklılaşmakta ve çoğalmaktadır. Kavramın günümüzdeki karşılığı toplumsal ve siyasaldır (Emiroğlu ve diğerleri, 2003). Toplum, eylem, deneyim ve ilişkilerin zeminidir. Her eylem, deneyim ve ilişki sosyal yapının verileriyle belirlenir. Dünyaya firlatıldığımızda bir boşluğa değil, sosyal ilişkilenmeler ağına düş̧eriz. Bütün hususiyetlerimiz oradan gelir (Heidegger, 2008: 135). Dolayısıyla bireyin siyasal tercihlerinin, toplumsal davranışlarının ve kendilerine ilişkin tasarımlarının bizzat sosyal yapının verileriyle beslendiğini söyleyebiliriz

Siyasal kimlik, günümüzde sınıf kavramının yerine kullanılmakla birlikte ondan daha değişken, daha çok boyutlu ve belirleyici güce sahip ve siyasal önemde bir kavram olarak işlev görmektedir (Gürses, 2000: 221). Toplumsal yapının etkisi ile şekillenen düşünce ve değerlerin aktarım biçimi, kullanılacak yöntemlerin, dilin nasıl bir siyasi çizginin ürünü olacağı ile ilgili tercihlerin referansı siyasal kimliklerdir. Seçimlerde oy kullanan seçmenin, siyasi tercihlerini belirlerken sosyo-kültürel yapının etkili olduğu yerin odağında demokrasi kavramına aracılanmış olan siyasal kimliklerdir. Siyasi tercihlerin belirlenmesinde hangi faktörlerin etkili olduğu sorusu, siyaset sosyolojisi başta olmak üzere çeşitli disiplinlerin ilgi alanına girdiğini bu konuda yapılan araştırmaları örnek olarak gösterebiliriz.

Öncelikle vurgulanması gereken şey siyasal kimliklerin toplumun maddi ve manevi değerlerinden soyutlanamayacağıdır. Dolayısıyla siyasal kimlikler toplumun bir parçası olan bireyin toplumla olan etkileşimi süreci ile olgunlaşmaktadır diyebiliriz. Bu siyasal kimlikler yerelde veya ulusal düzeyde yansımasının esas unsurunu oluşturan siyasi seçimler ile bütünleşerek, sosyolojik bir güç odağına dönüşmek suretiyle seçimlerde belirleyici unsur olarak karşımıza çıkmaktadır.

Bireylerin yaşam tarzları gündelik yaşam pratiklerini, çeşitli olaylara bakışlarını, siyasal kimliklerini ve siyasal tercihlerini de etkileyebilmektedir. Hayat tarzı, bireylerin değerleri, ilgi alanları, sosyal ilişkileri, gündelik yaşam içerisindeki pratiklerini de kapsayan bir olguyu ifade etmektedir. Hayat tarzı bakımından Türk Toplumu, Modern, Dindar Muhafazakâr ve Geleneksel Muhafazakâr olarak (Konda, 2012) üçlü bir sınıflandırmaya tabi tutulmuştur. Hayat tarzı gündelik olaylar, tüketim alışkanları gibi unsurlarda etkili olduğu gibi siyasal kimlik ve siyasal tercihte de etkili olabilmektedir. Burada hayat tarzı ile siyasal kimlik arasında diyalektik bir ilişkinin olduğunu ifade etmek yerinde olacaktır. Her iki olgu da birbirini etkileyebilmektedir.

$\mathrm{Bu}$ değerlendirmeler çerçevesinde bu çalışmada siyasal kimlik, yaşam tarzı ve siyasal tercih olguları Malatya ilinde yapılan bir araştırma ile çeşitli değişkenler tarafından analiz edilmekte, bu olguların bir birileri ile ilişkileri de ortaya konulmaya çalışılmaktadır.

Malatya tarihi Paleotik çağa kadar giden bir şehirdir. Malatya bölgesinde Hititler, Medler, Persler ve Romalılar hüküm sürdükten sonra 656 yılında İslam hükümranlığına geçmiştir. Selçuklular ve Osmanlılar döneminde önemli yerleşim merkezinden biri olarak varlığını sürdürmüştür.

Cumhuriyet ile birlikte 1924 yılında il olan Malatya'nın 2018 nüfus sayımına göre nüfusu 793.036'dır. Nüfusun \%49.7'si erkek, \%50.2'si ise erkektir (TÜIK). Malatya'nın seçmen sayısı 562.216'dır. 2019 yerel seçimlerinde Büyükşehir Belediye Başkanlığını AK Parti kazanırken; 8 ilçeyi AK Parti, 3 ilçeyi CHP, 1 İlçeyi MHP, 1 ilçeyi ise bağımsız belediye başkanı kazanmıştır. Seçimlerde siyasal partilerin aldıkları oylara göre, kentin siyasal eğilimlerinde muhafazakâr, demokrat, milliyetçi ve sosyal demokrat eğilimler öne çıkmaktadır. 


\section{KİMLİK VE KİMLİĞİN SİYASAL BOYUTU OLARAK SIYYASAL KİMLİK}

Aynıllğg, birbirine benzerliği içeren ve Latince "idem" kökünden gelen kimlik kavramı, uzun bir tarihi olmasına rağmen yirmi birinci yüzyıla kadar popüler olarak kullanılmamıştır (Marshall, 2003: 405). Antik ve skolastik dönem bir tarafa, geleneksel aydınlanma düşüncesi dahi insanın kamusal, aktif ve rasyonel oluşunun altını çizerken onları birer "aktör" olarak değerlendirmiştir. Oysa günümüzde bireyler artık bir aktör olarak değil, kimlikleriyle tanınma sürecine girmişlerdir (Sözen, 1999:11). Bu noktadan baktığımızda günümüzde bireyi diğerlerinden ayırt eden farklılıklarının ifadesi olan kimlik, esasında kişinin parmak izi olarak da değerlendirilebilir. Makalenin giriş bölümünde de belirtildiği gibi Henry E. Brady ve Cynthia Kaplan gibi kimlik üzerinde çalışan siyaset bilimcilerinin çoğu, kimliğin etnik köken, grup düzeyinde bireyler arasındaki temas ve sosyalleşme gibi bağlamsal aktörlerin etkilediği bireysel seçimlerin bir ürünü olduğunu vurgulamışlardır (Rogers, 2004:306).

Maloof (2000:16) kimliği ifade ederken "kimliğim beni başka hiç kimseye benzemez yapan şeydir" değerlendirmesini yaparak bireyi farklı kılan unsur olma özelliğine dikkat çekmektedir. Kimlik; toplumsal, kültürel, siyasal ekonomik ve psikolojik bir yapılanma süreci olduğu için asla sabit bir yapı arz etmez; karmaşık ve değişken olduğundan sürekli yeniden konumlanır (Parmar, 1998: 19-20). Bundan dolayıdır ki kimlik esasında, yaşamsal deneyimlerin, toplumsal etkilerin, sosyo-ekonomik ilişkilerin, geçmiş ve gelecek dinamiklerin etkisiyle sürekli kendisini yenilemesi hasebiyle bir çerçeveye sığdırmanın daha ötesidir. Bu kesişmede kimlik oluşurken hâkim olacak ve belirleyecek nihai bir karar verici yoktur (Rutherford, 1998: 20). Buradan hareketle bugün sosyoloji, sosyal psikoloji, felsefe, edebiyat, siyasal bilimler, antropoloji gibi birçok disiplinin kimliği kendi bakış açılarıyla tanımlama çabaları bu çerçevenin sınırlarını her geçen gün biraz daha genişletmektedir. Ancak bir kimlik bağlamı içinde doğan bireye, sosyal olarak yüklenen anlamlar, kişi tarafindan kabul edilmedikçe ve özdeşim kurulmadıkça, kendi başına bireyi tanımlamadığı için kimliği tanımlayan bireyin kendisidir (Tok, 2003: 124) denilebilir. Aydoğdu (2004:10), kimlik tanımlanmasındaki çok boyutluluk ve çeşitliliğe rağmen tanımların tümünün merkezinde "özne" olma vurgusunun olmasının; kavramın tanımı, çözümlenmesi ve sorgulanmasını kolaylaştırdığını belirtmektedir. Kimlik her ne kadar birey için ayırt edici özelliklerin aracı olarak değerlendirilse de diyalektik anlamda ise bir yere ait olmanın, bir yerde kendini konumlandırmanın belirsizlikten kaçmanın da limanıdır diyebiliriz.

Kimlik bir kişinin, bir grubun üyesi olarak tanımlanabilmesinin yanı sıra bireyin kişisel özellikler seti olarak da değerlendirilebilir. Kimlik, toplumu anlamak üzere araçsallaştırılan statü, parti ve sınıf benzeri bir zihnî kategoridir (Altunoğlu, 2009:6). Kaçınılamaz bir biçimde kolektif ve kültürel, etnik ve siyasal boyutlarıyla tanımlanan kimlik; bir toplumsal yapıda cinsiyet ve yaş takımlarına, uluslardan birine, ailede ve meslekte bir role ve ideolojik bir katılıma bağlı olmak gibi geniş bir alanı kapsar (Ergun, 2000: 80). Kimliğin farklı boyutları da bulunmaktadır. Toplumsal kimlik, etnik kimlik, kültürel kimlik, ulusal kimlik ve siyasal gibi farklı kimlik boyutları vardır.

Siyasal kimlik tanımlarken esas olarak o kimliği paylaşanlar arasında bir tür içsel yakınlığın olup olamadığı sorusu çıkış noktası olmuştur. Bundan dolayı, siyasal kimlik konusu genellikle ulusal üyelik, sınıf aidiyeti ve bir ideolojik aklın dışında tutulamaz. Çünkü toplumsal/siyasal kimlik, kimliğin kişiler arası düzeydeki ifadesidir. Benliğin, belirli bir sosyal gruba ait olduğu hakkındaki bilgi veya bilincine dayanır. Bu bilinç veya bilgiler, söz konusu gruba aidiyete ilişkin bir takım duygular ve değer atıflarıyla birlikte bulunur (Bilgin, 2007: 13). Dolayısıyla siyasal kimlik bir etkiler süreci ile birlikte birey dünyasında yavaş yavaş inşa edilir. Kökeni ne olursa olsun, bir mekânsal ve toplumsal konumun varllğına, kişinin doğduğu ve çocukluğunu geçirdiği bir yer ve aile ocağı olarak vatana, bütün yurttaşların dâhil olduğu bir siyasal katılıma, ahlaki, ekonomik ve hukuki bir yurttaşlığa ve bütün nüfusun okur-yazar olmasını içeren bir sivil eğitim vurgusu gibi oluşturuculara ihtiyaç duyan siyasal kimliğin, tarafsız bir kavram olmadığı söylenebilir (Smith, 1999: 182-184).

Siyasi kimlik, kişilerin siyasi aktörler tarafindan bir siyasi grubun üyeleri olarak tanındığı bir dizi özellik için ortak bir etiket olarak algılanabilir. Çünkü siyaset üzerinden bir kimlik edinmek, insanoğlunun modern dönemdeki tecrübelerinden biri olarak karşımıza çıkmaktadır.

Siyasal kimlikler, daha önce de belirttiğimiz gibi bir yönüyle siyaset, diğer yönüyle kimlik oluşum süreci üzerinden oluşturulmaktadır (Göktolga,2012:112). Örneğin, kimlik kavramının, ulus yaratma sürecinde önemli rol oynadığı düşünen Anderson, kimliklerin aslında kurgusal olduğunu belirterek onları toplumsal iletişimin bir ürünü olarak görmüştür (Anderson, 1993: 21). Çünkü siyasal kimlik bir kültür siyasasının birikimi neticesinde günümüz dünyasında toplumun kendisini temellendirmenin katalizörü işlevini görmektedir.

Bireyin sonradan edindiği bir tanımlama aracı olan siyasal kimliğin, geniş çapta aydınlar sınıfı tarafından oluşturulduğu iddia edilmiştir. Batı Avrupa'da yaşanan ekonomik ve siyasi gelişmelerin yeni tipte bir orta 
sınıfı (burjuvazi) ortaya çıkarması, kimlik kavramının çok yönlü gelişmesini sağlamış ve ona daha önce benzeri görülmemiş bir siyasi boyut kazandırmıştır (Karpat, 2006: 61). Siyasal alanın anlaşılması açısından siyasal kimlik, bireylerin zihinsel ve eylemsel olarak kendilerini bir grubun üyesi olarak belirli bir yere konumlandırmasıyla eklemlenmiş durumdadır. Dolayısıyla siyasal kimlik yerelde ve ulusal düzeyde var olan düşünsel yapılanmalardan bağımsız olarak değerlendirilemezler.

\section{SIYYASAL KİMLIĞİiN OLUŞMASINA ETKİ EDEN FAKTÖRLER}

Amin Maalouf (2000: 37) kimliğin öyle bir çırpıda verilmediğini, yaşam boyunca oluştuğunu ve değiştiğini ifade ederek, kimlik oluşumunu bir süreç olarak nitelendirmenin yanında aynı zamanda değiştiğine de dikkat çekmektedir. Kimliklerin inşası, tarihten, coğrafyadan, biyolojiden, üretken ve üremeye yönelik kurumlardan, kolektif hafızadan, kişisel fantezilerden, iktidar aygıtlarından ve dinsel vahiylerden malzemeler kullanır. Ama bireyler, toplumsal gruplar, toplumlar bütün bu malzemeyi, içinde bulundukları toplumsal yapıya, uzam/zaman çerçevesinden kaynaklanan toplumsal koşullara ve kültürel projelere göre işler, bütün bu malzemenin anlamını yeniden düzenler (Castells, 2006: 14). Kimlik, özgürlük ve bireycilik gibi, ancak toplum içinde ve toplumdan geçerek oluşur ve oluşturulur. Hiç kimse toplumun dişında, toplumdan bağımsız bir kimliğe, özgürlüğe ve bireyselliğe sahip olamaz: İnsan ancak toplumda özgürdür veya köledir. Bireyin ne olduğu, özgürlüğü ve bireyciliği ancak toplumla vardır. Bireyin kimliği, özgürlüğü, zenginliği ve yoksunluğu amaçlı ve örgütlü faaliyetler içinde diğer bireylerden geçerek olur (Erdoğan, 2006: 8).

Kimlik belirleme ya da kimlik oluşumu, çevresindeki anne-baba ve tanıdık, eş, dost kişiler gibi, ilk toplumsal alanın biçimlendirdiği ya da tanıdığı kimliklerin referansıyla kimliğini oluşturan özne tarafindan belirlenen bir süreçtir ( Ekinci, 2008: 158). Bu süreci toplumsallaşma süreci olarak nitelendirmekteyiz. Bozkurt (2004: 111) toplumsallaşmanın bir taraftan bireylere kimlik kazandırırken diğer taraftan da toplumun kültürünü kuşaktan kuşağa aktardığını ifade ederek, sosyalleşmenin bireysel ve toplumsal önemine değinmektedir. Bu manada birey toplumsallaşma süreci ile yaşadığı toplumun bir parçası, bir öğesi olmakta ve bu yine bu süreçte bir kimlik kazanmaktadır.

Toplumsallaşma sürecinin önemli bir boyutunu da siyasal toplumsallaşma ifade etmektedir. Siyasal toplumsallaşma, bireylerin politik inanç ve tutumları elde etme sürecidir (Rob, 2007: 2). Diğer bir tanıma göre ise, siyasal toplumsallaşma, siyasal değerler ile toplum üyeleri arasında ilişki ve bu siyasal değerlerin bireylere aktarılma süreci (Türkkahraman, 2000: 23) olarak ifade edilmektedir.

Siyasal toplumsallaşma, bireylerin siyasal toplumdaki yerlerini nasıl bulacağı ve onların siyasal amaçlar, aktörler, semboller ve süreçlere karşı bireysel tutumlarını nasıl keşfedeceğini (Schwarzer, 2011: 2) ortaya koymaktadır. Siyasal toplumsallaşma ile bireyler, siyasal sistemde rol oynamaya hazır birer "siyasal insan" haline gelirler. Bu süreçle bireyler siyasal sistemin değerlerini, kurallarını, inançlarını, eğilimlerini ve davranışlarını öğrenir, neler yapmaları gerektiğini kavrar ve ne tür rol oynayacaklarını bilirler (Dursun, 2012: 221).

Siyasal toplumsallaşma sürecinde bireyin siyasal bir insan olmasını diğer bir ifadeyle siyasal kimlik kazanmasını etkileyen araçlar olarak, aile, akran grupları, okul ve kitle iletişim araçları başta olmak üzere, hukuk, din görevlileri, büyük toplumsal hareketleri komşuluk ilişkileri, kültürel inanç sistemi, kanaat önderleri, sivil toplum kuruluşlarını (Rob, 2007:3; Rosengren,1994: 6, Arnet,1995: 617) ifade etmek mümkündür.

Bunların yanında siyasal partiler ve siyasal alanı biçimlendiren ideolojilerin de siyasal kimliklerin oluşumunda yadsınamaz bir etkisi bulunmaktadır. Çünkü siyasal alan ideoloji ve siyasal partiler ekseninde şekillendiğinden bireyler üzerinde etkisi de güçlü olabilmektedir. Özellikle siyasal partiler, kurumsal yapılarının da verdiği güç ile siyasal alanın hemen her boyutunda olduğu gibi siyasal kimlik oluşumunda etkindir. Göktolga'ya göre ( 2012: 188) siyasal partiler ile siyasal kimlik arasında diyalektik bir ilişki vardır. Siyasal partiler, siyasal kimlikler üzerinden inşa edilirken, siyasal partiler de siyasal kimliklerin oluşumunda temel belirleyici olmuştur.

Siyasal kimlik siyasal kültür, toplumsal kültür başta olmak üzere uluslararası kültür hareketlerinden beslenmektedir. Ulusal düzeyde baktığımızda siyasal kimlik oluşumunda rejim ve devlet boyutunun önemli bir yer teşkil ettiğini rahatlıkla söyleyebiliriz. Devlet, geleneksel kimlikler içinde bunalmış bireye/yurttaşa yeni kimliklerini benimsetmek için tarihi de kendi açısından yeniden yorumlamış, bir kişinin sahip olabileceği temel kimlikleri yeni bir sınıflandırmaya tabi tutarak yeni bir siyasi insan ortaya çıkarmıştır. Dolayısıyla günümüzde tartışılan kimlik sorunu daha ziyade siyasi kimliktir ve ulus-devletlerin ortaya çıkmasından itibaren daha fazla önem kazanmıştır (Karpat, 2006: 67-69). Siyasal kimliklerin oluşumunun Batı ve Türkiye açısından kronolojik ve sosyolojik anlamda benzer merhalelerden geçtiğini söyleyemeyiz.

Avrupa modern siyasasının bükülgenliğine büyük ölçüde katkıda bulunan siyasal kimliklerin ortaya çıkması bir takım çapraz bölünmeler etkisiyle gerçekleşmiştir (Mardin, 1990: 32). Avrupa' da siyasal kimlikler 
ve tercihler toplumun çatışmalara dökülmüş biçimleri olarak sosyal yapıya yerleşmişlerdir ve sosyal bölünmüşlüğü yansıtmaktadırlar. Sanayileşme ya da uluslaşma sürecinin bir sonucu olarak ortaya çıkan sosyal yapıdaki bölünmeler ya da değer çatışmaları günümüz dünyasında Batı'daki siyasal kimlikleri şekillendirmiştir (Lipset ve Rokkan, 1967: 5-6). Dolayisıyla kitlesel bir serüvenin sonucu olan siyasal kimliklerin oluşumunda bireyin iç dinamiklerinin yanısıra, sosyal yaşamın da belirleyici fonksiyonları vardır. Bireysel anlamdaki kazanımlarımız kendimizi dışa karşı konumlandırma biçimimiz kadar, bireyin sosyalitesi üzerinde egemen olan şeyler de siyasal kimlik oluşumunda etkilidir. Paradoksal olarak kimlik bir taraftan kendimizi ifade biçimimiz diğer taraftan egemen olan şeyler tarafindan dayatılan bir olgudur. Yasalar, din, bireyin yaşam alanında sürekli var olan aile, okul, arkadaşlıklar, siyasal kültürün erkleri kimliklerimizin üzerinde belirleyici bir rol oynamaktadirlar.

Türkiye'de siyasal kimliklerin oluşumu ve değişimi ağırlıklı olarak merkez-çevre dikotomisi çerçevesinde ele alınmaktadır. Tanzimat'tan bu yana Türk siyasal yaşamını açıklamada anahtar kavram olan merkez-çevre dikotomisinin, bugün geldiğimiz süreçte de toplumsal ve siyasal bölünmeyi tasvir etme kabiliyetini kaybetmediği anlaşılmaktadır. Ancak, değişen toplumsal değer ve semboller, sahip olunan ideoloji, ait olunan kültür, etnik köken ve toplumsal statü gibi pek çok unsurdan etkilenen siyasal kimliklerin değişen yapısının, merkez-çevre dikotomisinden daha detaylı bir ayrıma tabi tutularak incelenmesi ve bu karmaşı yapıyı ortaya koyan bir kavramlaştırmaya gidilmesi doğru olacaktır. Cumhuriyetin kuruluş yıllarından çok partili hayata geçiş sürecine kadar parti-devlet sisteminin yaşandığı Türkiye'de modernleşme ve uluslaşma sürecinin baş aktörü konumunda bulunan CHP, uyguladığı politikalarla, sahip olduğu ilkelerin jakoben nitelikler taşıması ve tepeden modernleşme yönteminin halka dayatılması sebebiyle çevrenin marjinalleşmesine, hatta merkezden soğumasına neden olmuş, çevrenin siyasal örgütlenmesi uzun yıllar boyunca merkez ve marjinal sağın çeşitli partileri üzerinden gerçekleşmiştir (Göksu, 2013: 87-89). Türkiye'de siyasal kimliğin oluşması ve şekillenmesinde rasyonel olan ya da olmadığı ifade edilen birçok olgu ve anlayış büyük rol oynamıştır. Türkiye'de siyasal kimlik oluşum sürecini net biçimde anlayabilmek adına geriye gidilmelidir. Kurtuluş Savaşı Dönemi'nden günümüze kadar birçok dönem içerisinde cereyan eden durum ve olgulara göre şekillenen siyasal kimlik, bireyin siyasi bir arayış içerisine girmesi ile birlikte oluşmaya başlamış, bireysel bağlamda genellikle aile ve çevresinin etkisi ile şekillenmiştir (Yegen, 2018: 87). Tek parti döneminden çok partili hayatın başlangıcı 1950 yılına kadar geçen süre ulus devlet bilinci çerçevesinde siyasal kimlik şekillenmesinin yaşandığ bir süreçtir. 1950'den sonraki süreç ise demokratik eğilimler ortaya çıktığ bir süreç olarak değerlendirilirken sonraki süreçlerde ülke ya da küresel sistemden kaynaklanan gelişmeler çerçevesinde yeni eğilimler ortaya çıkmıştır. Türkiye'de siyasal kimlik oluşumunda travmatik siyasal deneyimlerin de önemli bir etkisi bulunmaktadır. Bu anlamda 1960 ve 1980 askeri darbeleri ile 28 Şubat postmodern darbesi, 27 Nisan emuhtırası ve 15 Temmuz hain darbe girişimi de bu anlamda Türkiye' de siyasal kimliklerin taşınmasında ve yeniden biçimlenmesinde önemli süreçler olarak değerlendirilebilir.

Tüm bu değerlendirmeler 1şığında siyasal kimliklerin oluşumunda temel paradigmaları ortaya koymanın zor olduğunu söyleyebiliriz. Çünkü devingen bir varlık olan insan bazen toplumsal bir siyasal kimlik oluşumuna aracılık ederken, bazen de devingen bir oluşum olan toplum bireyin siyasal bir kimliğe bürünmesine aracılık etmektedir.

\subsection{SIYYASAL KIMLİK VE SIYYASAL TERCİH İLIŞKİSI}

Siyasal kimlikler, siyasal parti kimlikleri ile büyük oranda örtüşmektedir. Siyasal kimlikler partiler üzerinden oluşturulup, siyasi partiler üzerinden işlevsel hale gelmektedir (Göktolga, 2012: 142). Bu anlamda siyasal kimlik ve siyasal parti arasındaki diyalektik ilişkinin yansımasını doğal olarak siyasal tercihte de görmek mümkündür. Emre'ye (1999) göre, İnsanımız siyasal tercihlerini değiştirmekten çok siyasal eğilimlerine, siyasi kimliğine uygun ya da yakın gördüğü partiye oy veriyor. Bu siyasal kimlikler de uzun vadede oluşan toplumsal eğilimlerin, etkileşimlerin sonucu olarak ortaya çıkıor ve kolay kolay değişmiyor. Ebetteki bu değerlendirmeler parti sadakati ve parti aidiyeti ile ilişkilidir. Günümüzde siyasal partilere seçmenin sadakati ve aidiyeti görece azalma görüldüğünden siyasal kimliklerinin de siyasal tercihine etkisi azalma gösterebilmektedir.

Siyasal kimlik ile siyasal tercih arasında anlamlı bir ilişkinin olduğu yapılan bazı çalışmalar ile ortaya konulmuştur. Doğan'ın (2014: 412) Türkiye genelinde yaptığ 1 bir araştırmaya göre, aile üyelerinde birinin isteği üzerine oy verme ile siyasi kimlik arasındaki ilişkiyi incelediğimizde muhafazakârların (\%20.4), İslamcıların (\%19.9) ve Türk milliyetçilerinin (\%14.5) daha yüksek oranda aile üyelerinden birinin isteği üzerine oy verdikleri belirlenmiştir. Diğer yandan sosyal demokratlar (\%14.7), İslamcılar (\%7.7) ve demokratların (\%5.4) daha yüksek oranda STK üyelerinden birinin isteği üzerine oy verdiği gözlemlenmiştir. 
Bir ülkenin ya da yerelin siyaset analizinin doğru bir zeminde yapılmasında orada var olan siyasal kimliklerin niteliğinin bilinmesi önemli rol oynamaktadır. Çünkü siyasal kimlikler ile siyasal tercihler arasında bir bağın söz konusu olduğu aşikârdır. Dolaysıyla siyasal kimlikler genelleme yaptığımızda o ülkenin, o yerelin siyasal açıdan bir çerçevesini çizmememizde yardımcı olacaktır. İnsanın her gün yaptığı sayısız davranış ve eylemler içerisinde bazısı siyaset olgusunun yaşandığı siyaset toplumundan, siyasal kurumlardan ve siyasal iktidar süreçlerinden gelen etkilere karşı verdiği tepkilerden oluşmaktadır ki biz bunlara siyasal davranış veya siyasal eylem diyoruz (Dursun; 2012: 214). Siyasal tercihleri meslek, yaş, cinsiyet, yerleşim yeri, eğitim gibi, sosyo-demografik ve gelir, tüketim kalıbı, refah düzeyi gibi sosyo-ekonomik değişkenler etkilemektedir (Baykal, 1970:83). Sosyo-ekonomik, psikolojik, kültür ve siyasal değişkenlerin etkisiyle oluşan siyasal kimlik, bireyin ve ya toplumun siyasal tercihlerini de kendini nitelendirmiş olduğu siyasal kimliğinin bakış açısına göre kullanacaktır. Tüm bunların yanı sıra toplumların gelişmişlik düzeyleri, yapısı, toplumsal mobilizede siyasal davranışı etkilemektedir. Bu nedenle az gelişmiş ya da gelişmekte olan çoğu ülkede siyasal davranışları Batı toplumları için ortaya konulmuş kuram ve yaklaşımlar açıklamakta yetersiz kalmakta, geleneksel toplumlarda siyasal kararalar gerektiği gibi rasyonel olarak değil, başka faktörlerin etkisiyle alınmaktadır (Gülmen, 1979: 2008-2012). Tüm bu değerlendirmeler 1şığında bireyin siyasal tercihinde etkili olan çok sayıda parametrenin (meslek, yaş, cinsiyet, ideoloji, siyasal parti, aile vb.) yanında siyasal kimlikler de belirli bir düzeyde etkili olabilmektedir.

\section{METODOLOJI}

$\mathrm{Bu}$ çalışmada alan araştırması yöntemi uygulanmıştır. Araştırma kapsamında elde dilen veriler anket tekniği ile toplanmıştır. Araştırmanın evrenini Malatya ili merkez ilçe sınırlarında 86 mahallede yaşayan ve seçmen hüviyetini taşıyan vatandaşlar oluşturmuştur.

Basit tesadüfi yöntemle örneklem grubu belirlenmiş ve yüz yüze görüşmeye dayalı olarak katılımcılara anket formu 2-14 Mart 2019 tarihleri arasında uygulanmıştır. Hatalı ve geçersiz anket formlarının çıkarılmasının ardından 1531 anket formu değerlendirmeye alınmıştır. Tarama modelinde olan bu araştırma betimsel bir nitelik arz etmektedir. Seçmen hüviyetine sahip 18 yaş ve üzerindeki vatandaşların siyasal kimlik, hayat tarzı ve siyasal tercihleri arasındaki ilişkilerinin analiz edilmesi amaçlanmaktadır. Çalışmada frekans analizi ve ki kare testi uygulanarak, elde edilen sonuçlar detaylı bir şekilde analiz edilmiştir.

\section{ARAŞTIRMA BULGULARI VE DEĞERLENDİRME}

\section{Tablo 1: Katılımcıların Cinsiyeti}

\begin{tabular}{|l|c|c|}
\hline & F & $\%$ \\
\hline Kadın & 737 & 51.9 \\
\hline Erkek & 794 & 48.1 \\
\hline Toplam & $\mathbf{1 5 3 1}$ & $\mathbf{1 0 0 , 0}$ \\
\hline
\end{tabular}

Anket katılımcılarından 794 kişi erkek (\% 51,9); 737 kişi (\% 48,1) ise kadındır. Kadın ve erkek katılımcıların oranının bir birine yakın düzeyde olması, nüfus dağılımıyla aynı düzeyde gerçekleşmiş olması bakımından kayda değerdir.

Tablo 2: Katılımcıların Yaşı

\begin{tabular}{|l|c|c|}
\hline & $F$ & $\%$ \\
\hline $18-25$ & 265 & 17,3 \\
\hline $26-35$ & 401 & 26,2 \\
\hline $36-45$ & 410 & 26,8 \\
\hline $46-55$ & 300 & 19,6 \\
\hline 56 ve üzeri & 155 & 10,1 \\
\hline Toplam & $\mathbf{1 5 3 1}$ & $\mathbf{1 0 0 , 0}$ \\
\hline
\end{tabular}

Ankete katılan örneklemin yaş aralığına göre dağılımı ise şu şekildedir; 265 kişi (\% 17,3) 18-25 yaş; 401 kişi (\% 26,2) 26-35 yaş; 410 kişi (\% 26,8) 36-45 yaş; 300 kişi $(\% 19,6)$ 46-55 yaş; 155 kişi $(\% 10,1)$ ise 56 ve üzeri yaş aralı̆̆ındadır. 
Tablo 3: Katılımcıların Eğitim Durumu

\begin{tabular}{|l|c|c|}
\hline & $\mathrm{F}$ & $\%$ \\
\hline Okur-Yazar Değil & 46 & 3,0 \\
\hline İlkokul & 251 & 16,4 \\
\hline Ortaokul & 408 & 26,6 \\
\hline Lise & 522 & 34,1 \\
\hline Lisans & 285 & 18,6 \\
\hline Lisansüstü & 19 & 1,3 \\
\hline Toplam & $\mathbf{1 5 3 1}$ & $\mathbf{1 0 0 , 0}$ \\
\hline
\end{tabular}

Katılımcıların eğitim durumları ise şu şekildedir; 46 kişi (\% 3,0) okur-yazar değil; 251 kişi (\% 16,4) ilkokul; 408 kişi $(\%$ 26,6) ortaokul; 522 kişi $(\%$ 34,1) lise; 285 kişi $(\%$ 18,6)lisans; 19 kişi $(\%$ 1,3) lisansüstü mezunudur.

Tablo 4: Katılımcıların Gelir Durumu

\begin{tabular}{|l|c|c|}
\hline & F & $\%$ \\
\hline 1500 ve alt1 & 187 & 12,2 \\
\hline $1501-2500$ & 825 & 53,8 \\
\hline $2501-4000$ & 404 & 26,4 \\
\hline $4001-6000$ & 82 & 5,4 \\
\hline 6001 ve üstü & 33 & 2,2 \\
\hline Toplam & $\mathbf{1 5 3 1}$ & $\mathbf{1 0 0 , 0}$ \\
\hline
\end{tabular}

Araştırma örnekleminden 187 kişi (\% 12,2) aylık 1500 TL altı gelir grubu, 825 kişi (\% 53,9) 1501 - 2500 TL; 404 kişi $(\%$ 26,4) 2501-4000 TL, 82 kişi $(\%$ 5,4) 4001- 6000 TL, 33 kişi $(\%$ 2,2) ise 6001 TL ve üzeri gelir grubunda yer almaktadır.

Tablo 5: Katılımcıların Hayat Tarzı Sinıflandırmaları

\begin{tabular}{|l|c|c|}
\hline & $\mathrm{F}$ & $\%$ \\
\hline Modern & 500 & 32,7 \\
\hline Geleneksel Muhafazakâr & 580 & 37,9 \\
\hline Dindar Muhafazakâr & 405 & 26,5 \\
\hline Diğer & 46 & 3,0 \\
\hline Toplam & $\mathbf{1 5 3 1}$ & $\mathbf{1 0 0 , 0}$ \\
\hline
\end{tabular}

Hayat tarzı, aile (sosyal sınıf), arkadaşlar (durum grupları, cinsiyet, kuşak) ve farklı hareket ve ağ türlerinden düzenlenmiş ve etkilenmiş alt kültürlerin rutin bir ifadesidir. Hayat tarzı, öz kimliğin dişa vurumu (Jensen, 2007: 65) olarak da nitelendirilmektedir. Hayat tarzı bireylerin gündelik yaşam pratiklerinin bir yansımasıdır. Nasıl giyinir, nereleri gezer, kimlerle arkadaşlık yapar, ne yer-içer, hangi işte çalışır, boş vakitlerinde neler yapar, iletişim araçlarını nasıl kullanır, ne tür kitaplar okur, siyasete ilgi düzeyi nedir, herhangi bir ideolojiye sahip midir gibi çok sayıda sorunun sistematik olarak gruplandırılması hayat tarzını ifade etmektedir.

Hayat tarzı bireylerin kendilerini konumlandırdıkları yerin bir takım değerlerini içselleştirmesi ve buna göre davranışta bulunmasının bir aracı olarak da değerlendirilebilir. Hayat tarzı sınıflandırmasında Türkiye'de genellikle Konda araştırma tarafından kapsamlı analizler sonucunda oluşturulan modern, geleneksel muhafazakâr, dindar muhafazakâr şeklinde üçlü sınıflandırma kullanılmaktadır. Araştırma kapsamında da katılımcılara bu sınıflandırmalar içerisinde kendini nasıl tanımladığı sorulmuştur.

Katılımciların \%32.7'si kendini modern olarak tanımlarken, \%37.9'u geleneksel muhafazakâr, \%26.5'i ise dindar muhafazakâr olarak tanımlamaktadır. Araştırmaya dâhil edilen örneklem grubuna geleneksel muhafazakâr ile dindar muhafazakâr oranının \% 64,4 ile önemli bir yere tekabül ettiğini ve bu oranın Malatya'da geçmiş dönemlerde yapılan yerel ve genel seçimlere siyasal tercihler ile karşıllı bulduğunu söyleyebiliriz. 
Tablo 6: Siyasi Tercihe Göre Hayat Tarzi Sinıflandırması

\begin{tabular}{|c|c|c|c|c|c|c|}
\hline \multirow{2}{*}{\multicolumn{2}{|c|}{$\begin{array}{l}\chi^{2}=5,518 ; \mathrm{sd}: 24 ; \mathrm{p}: \\
, 000\end{array}$}} & \multicolumn{4}{|c|}{ Hayat Tarzı Sınıflandırması } & \multirow[t]{2}{*}{ Toplam } \\
\hline & & \multirow{2}{*}{$\begin{array}{l}\text { Modern } \\
20,4 \% \\
\end{array}$} & \multirow{2}{*}{$\begin{array}{c}\begin{array}{c}\text { Geleneksel } \\
\text { Muhafazakâr }\end{array} \\
43,5 \%\end{array}$} & \multirow{2}{*}{$\begin{array}{c}\begin{array}{c}\text { Dindar } \\
\text { Muhafazakâr }\end{array} \\
34,3 \% \\
\end{array}$} & \multirow{2}{*}{$\begin{array}{l}\text { Diğer } \\
1,8 \% \\
\end{array}$} & \\
\hline \multirow{9}{*}{ 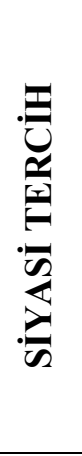 } & AK Parti & & & & & $100,0 \%$ \\
\hline & CHP & $84,1 \%$ & $11,8 \%$ &, $6 \%$ & $3,5 \%$ & $100,0 \%$ \\
\hline & MHP & $39,2 \%$ & $42,3 \%$ & $15,8 \%$ & $2,7 \%$ & $100,0 \%$ \\
\hline & HDP & $68,6 \%$ & $14,3 \%$ & $5,7 \%$ & $11,4 \%$ & $100,0 \%$ \\
\hline & Saadet Partisi & $5,0 \%$ & $20,0 \%$ & $70,0 \%$ & $5,0 \%$ & $100,0 \%$ \\
\hline & İẎ Parti & $46,7 \%$ & $36,7 \%$ & $13,3 \%$ & $3,3 \%$ & $100,0 \%$ \\
\hline & Diğer & $50,0 \%$ & & & $50,0 \%$ & $100,0 \%$ \\
\hline & $\begin{array}{l}\text { Oy } \\
\text { Kullanmadım }\end{array}$ & $29,0 \%$ & $30,6 \%$ & $27,4 \%$ & $12,9 \%$ & $100,0 \%$ \\
\hline & Cevap Yok & $38,6 \%$ & $36,8 \%$ & $21,1 \%$ & $3,5 \%$ & $100,0 \%$ \\
\hline \multicolumn{2}{|c|}{ Toplam } & $32,7 \%$ & $37,9 \%$ & $26,5 \%$ & $3,0 \%$ & $100,0 \%$ \\
\hline
\end{tabular}

Araştırma örneklem grubunun siyasi tercihleri ile hayat tarzı sınıflandırmaları arasında anlamlı bir ilişki bulunmaktadır. AK Parti seçmeni daha yüksek oranda kendini Geleneksel Muhafazakâr ve Dindar Muhafazakâr olarak tanımlarken MHP ve İYİ Parti seçmeni daha yüksek oranda Geleneksel Muhafazakâr ve Modern, Saadet Partisi Seçmeni ise kendi daha yüksek oranda Dindar Muhafazakâr olarak nitelendirmektedir. CHP seçmeni ve HDP seçmeni ise kendini daha yüksek oranda Modern olarak tanımlamaktadır.

Tablo 7: Katılımcıların Etnik Kimlik Tanımlamaları

\begin{tabular}{|l|c|c|}
\hline \multicolumn{3}{|c|}{$\begin{array}{c}\text { Genel olarak kendinizi daha çok hangi } \\
\text { kimlikle tanımlarsını? }\end{array}$} \\
\hline & F & $\%$ \\
\hline Türk & 1058 & 69,1 \\
\hline Kürt & 426 & 27,8 \\
\hline Zaza & 38 & 2,5 \\
\hline Arap & 4 & 0,3 \\
\hline Diğer & 5 & 0,3 \\
\hline Toplam & 1531 & 100,0 \\
\hline
\end{tabular}

Etnik kimlikler, insanın tarihselliğinin bir uzantısı olmasının yanı sıra bir iletişim süreci ile beraber yaşam pratikleri sunan ve toplumsal boyutu ile bireyin aidiyet duygusunun oluşmasına aracılık etmektedir. Araștırma kapsamında örneklem grubunun \%69.1'i kendi Türk, \%27.8'i Kürt, \%2.5'i Zaza ve \%0.6 diğer kimlik ile kendini tanımlamıştır. Tabloya göre Malatya ölçeğinde baktığımızda Türk kimliği kavramı ile kendilerini tanımlayanların \% 70 seviyesinde olması ve buna paralel olarak da hayat tarzı bakımından muhafazakârların yakın oranda belirlenmiş olması dikkat çekicidir.

\section{Tablo 8: Katılımcıların Dini Kimlik Tanımlamaları}

\begin{tabular}{|l|c|c|}
\hline \multicolumn{3}{|c|}{$\begin{array}{c}\text { Kendinizi Dini kimlik olarak nasıl } \\
\text { tanımlarsınız? }\end{array}$} \\
\hline & $\mathrm{F}$ & $\%$ \\
\hline Müslüman & 864 & 56,4 \\
\hline Sünni-Müslüman & 622 & 40,6 \\
\hline Alevi-Müslüman & 19 & 1,2 \\
\hline Diğer & 26 & 1,7 \\
\hline Toplam & 1531 & 100,0 \\
\hline
\end{tabular}

Bireylerin ya da toplumların kendilerini tanımlamada referans aldıkları temel kavramlardan bir diğeri de dini kimliktir. Bireysel yaşantıda var olan zihinsel alt yapının oluşmasında önemli bir kaynak olan din, yaşama katılma biçimlerini, sosyal yapılar içerisinde kendilik bilincini şekillendiren ve bireyi toplum nazarında konumlandıran önemli yapıların başında gelmektedir. Tabloya göre katılımcıların \%56’ü kendini Müslüman, 
\%40.6'sı Sünni Müslüman, \%1.2'si ise Alevi Müslüman olarak tanımlamaktadır. Toplamda katılımcıların \%98.3'ü Müslüman kimliğine sahiptir. Katılımcıların \%1.7'si ise Diğer seçeneğini işaretlemişleridir. Tablo Müslüman bir ülke olarak nitelendirilen Türkiye fotoğrafının bir örneği olarak karşımıza çıkmaktadır. Bu çerçevede baktığımızda Müslüman, Sünni-Müslüman, Alevi-Müslüman gibi inanç biçimlerinin siyasal kimliklerin oluşumunda önemli bir yer teşkil ettiklerini söyleyebiliriz.

Tablo 9: Hayat Tarzı Göre Dini Kimlik Tanımlamaları

\begin{tabular}{|c|c|c|c|c|c|c|}
\hline \multirow{2}{*}{\multicolumn{2}{|c|}{$\begin{array}{l}\chi^{2}=198,308 ; \mathrm{sd}: 9 ; \mathrm{p}: \\
, 000\end{array}$}} & \multicolumn{4}{|c|}{ Kendinizi dini kimlik olarak nasıl tanımlarsınız? } & \multirow{3}{*}{$\begin{array}{r}\text { Toplam } \\
500\end{array}$} \\
\hline & & \multirow{2}{*}{$\begin{array}{c}\text { Müslüman } \\
346\end{array}$} & \multirow{2}{*}{$\begin{array}{c}\begin{array}{c}\text { Sünni- } \\
\text { Müslüman }\end{array} \\
126\end{array}$} & \multirow{2}{*}{$\begin{array}{c}\begin{array}{c}\text { Alevi- } \\
\text { Müslüman }\end{array} \\
13\end{array}$} & \multirow{2}{*}{$\begin{array}{c}\text { Diğer } \\
15\end{array}$} & \\
\hline \multirow{8}{*}{ 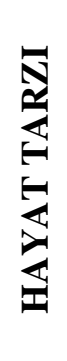 } & \multirow[t]{2}{*}{ Modern } & & & & & \\
\hline & & $69,2 \%$ & $25,2 \%$ & $2,6 \%$ & $3,0 \%$ & $100,0 \%$ \\
\hline & \multirow{2}{*}{$\begin{array}{l}\text { Geleneksel } \\
\text { muhafazakâr }\end{array}$} & 321 & 251 & 5 & 3 & 580 \\
\hline & & $55,3 \%$ & $43,3 \%$ & $0,9 \%$ & $0,5 \%$ & $100,0 \%$ \\
\hline & \multirow{2}{*}{$\begin{array}{l}\text { Dindar- } \\
\text { muhafazakâr }\end{array}$} & 166 & 238 & 1 & 0 & 405 \\
\hline & & $41,0 \%$ & $58,8 \%$ & $0,2 \%$ & $0,0 \%$ & $100,0 \%$ \\
\hline & \multirow[t]{2}{*}{ Diğer } & 31 & 7 & 0 & 8 & 46 \\
\hline & & $67,4 \%$ & $15,2 \%$ & $0,0 \%$ & $17,4 \%$ & $100,0 \%$ \\
\hline \multirow{2}{*}{\multicolumn{2}{|c|}{ Toplam }} & 864 & 622 & 19 & 26 & 1531 \\
\hline & & $56,4 \%$ & $40,6 \%$ & $1,2 \%$ & $1,7 \%$ & $100,0 \%$ \\
\hline
\end{tabular}

Katılımcıların hayat tarzı ile dini kimlikleri arasında diyalektik bir ilişkinin olduğu görülmektedir. Tabloda da görüldüğü üzere modern hayat tarzına sahip olduğunu düşünenler kendini Müslüman olarak tanımlarken, geleneksel muhafazakâr ve dindar muhafazakârlar daha yüksek oranda kendini Sünni Müslüman olarak ifade etmektedir. Bir başka açıdan ise, Müslüman kimlik üzerinden kendini tanımlayanların \%69,2'si modern, \% 55,3'ü geleneksel muhafazakâr, \% 41,0'1 ise dindar muhafazakâr bir hayat tarzını benimsemektedir.

Tablo 10: Katılımcıların Siyasal Kimlik Tanımlamaları

\begin{tabular}{|l|c|c|}
\hline \multicolumn{3}{|c|}{$\begin{array}{c}\text { Aşağıdaki siyasi kimliklerden hangisi sizi en } \\
\text { uygun olarak tanımlamaktadır? }\end{array}$} \\
\hline & $\mathrm{F}$ & $\%$ \\
\hline Muhafazakâr & 689 & 45,0 \\
\hline Milliyetçi & 396 & 25,9 \\
\hline Atatürkçü & 125 & 8,2 \\
\hline İslamcı & 126 & 8,2 \\
\hline Demokrat & 63 & 4,1 \\
\hline Sosyalist & 53 & 3,5 \\
\hline Sosyal Demokrat & 40 & 2,6 \\
\hline Diğer & 39 & 2,5 \\
\hline Toplam & 1531 & 100,0 \\
\hline
\end{tabular}

Kavram olarak kimlik, kolektif aidiyetlerden başka, arzularımız, hayallerimiz, kendimizi tasavvur etme, yaşama ilişki kurma-tanınma biçimimiz gibi hayattaki duruş yerimizi bildiren niteliklerin toplamını ifade etmektedir (Bostanc1, 1998: 42). Bunun yanı sıra siyasal kimliklerin varlığı siyasal partilerin yaşam serüvenlerinde ve kendilerini konumlandırma biçimlerinde aynı etkidedir. Bunu biçimlendiren faktörler arasında Milliyetçilik, Muhafazakârlık, İslamcılık, Atatürkçülük; Demokratlık gibi kavramlar toplumsal bir ayrışmaya veya bireyin ait olma ihtiyacına aracılık etmesinin yanı sıra siyasal partilerin kendi ideolojisine yakın kitlelerle iletişim kurma biçimini de düzenlemektedir.

Katılımcıların \%45.0'ı kendini muhafazakâr, \%25.9'u milliyetçi, \%8.2'si İslamc1, \%4.1'i demokrat olarak sağ siyasi yelpaze çerçevesinde şekillenen kimlikler bağlamında tanımlamaktadır. Diğer yandan katılımcıların \%8.2'si Atatürkçü, \%3,5'i sosyalist, \%2,6'sı ise sosyal demokrat kimlikleriyle sol siyasi yelpazede şekillenen kimlikler çerçevesinde tanımlamaktadır. Bu dağılım siyasal tercihler ile benzer bir eğilim ortaya koymaktadır. Sağ siyasi yelpazede şekillenen siyasal kimlikler ile kendini tanımlayan katılımcıların oranı \%83.2 iken, 24 Haziran 2018 genel seçimlerinde sağ siyasi yelpazede siyaset yapan siyasi partilerin (AK Parti, MHP, SP) aldıkları oyların toplamı yaklaşık olarak \%76'dır. Sol siyasi yelpazede kendimi tanımlayan katılımcıların oranı \%14.3 iken siyasi yelpazede siyaset yapan siyasi partilerin (CHP, Vatan ) aldıkları oyların toplamı yaklaşık olarak \%17 olarak gerçekleşmiştir. 
Tablo 11: Hayat Tarzı ile Siyasi Kimlik Tanımlamaları Arasındaki İlişki

\begin{tabular}{|c|c|c|c|c|c|c|c|c|c|c|}
\hline \multirow{2}{*}{\multicolumn{2}{|c|}{$\begin{array}{c}\chi^{2}=508,285 ; \text { sd: } 21 \\
\text { p: }, 000\end{array}$}} & \multicolumn{8}{|c|}{ Aşağıdaki siyasi kimliklerden hangisi size en uygundur? } & \multirow{3}{*}{$\begin{array}{c}\text { Toplam } \\
\\
500 \\
\end{array}$} \\
\hline & & \multirow{2}{*}{$\begin{array}{c}\begin{array}{c}\text { Muhafa- } \\
\text { zakâr }\end{array} \\
140\end{array}$} & \multirow{2}{*}{\begin{tabular}{|l}
$\begin{array}{c}\text { Milli- } \\
\text { yetçi }\end{array}$ \\
124 \\
\end{tabular}} & \multirow{2}{*}{$\begin{array}{c}\text { Demok- } \\
\text { rat } \\
37\end{array}$} & \multirow{2}{*}{$\begin{array}{c}\begin{array}{c}\text { Sosyal } \\
\text { Demo- } \\
\text { krat }\end{array} \\
20\end{array}$} & \multirow{2}{*}{$\begin{array}{c}\begin{array}{c}\text { Sosya- } \\
\text { list }\end{array} \\
40\end{array}$} & \multirow{2}{*}{\begin{tabular}{|c|} 
Atatürkçü \\
107 \\
\end{tabular}} & \multirow{2}{*}{$\begin{array}{c}\text { İslamc1 } \\
\\
13 \\
\end{array}$} & \multirow{2}{*}{$\begin{array}{c}\begin{array}{l}\text { Di- } \\
\text { ger }\end{array} \\
19 \\
\end{array}$} & \\
\hline \multirow{8}{*}{ 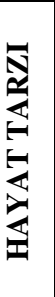 } & \multirow[t]{2}{*}{ Modern } & & & & & & & & & \\
\hline & & $28,0 \%$ & $24,8 \%$ & $7,4 \%$ & $4,0 \%$ & $8,0 \%$ & $21,4 \%$ & $2,6 \%$ & $3,8 \%$ & $100,0 \%$ \\
\hline & \multirow{2}{*}{$\begin{array}{l}\text { Geleneksel } \\
\text { Muhafazakâr }\end{array}$} & 305 & 197 & 18 & 12 & 5 & 11 & 19 & 13 & 580 \\
\hline & & $52,6 \%$ & $34,0 \%$ & $3,1 \%$ & $2,1 \%$ & $0,9 \%$ & $1,9 \%$ & $3,3 \%$ & $2,2 \%$ & $100,0 \%$ \\
\hline & \multirow{2}{*}{$\begin{array}{l}\text { Dindar- } \\
\text { Muhafazakâr }\end{array}$} & 238 & 65 & 7 & 6 & 3 & 0 & 85 & 1 & 405 \\
\hline & & $58,8 \%$ & $16,0 \%$ & $1,7 \%$ & $1,5 \%$ & $0,7 \%$ & $0,0 \%$ & $21,0 \%$ & $0,2 \%$ & $100,0 \%$ \\
\hline & \multirow[t]{2}{*}{ Diğer } & 6 & 10 & 1 & 2 & 5 & 7 & 9 & 6 & 46 \\
\hline & & $13,0 \%$ & $21,7 \%$ & $2,2 \%$ & $4,3 \%$ & $10,9 \%$ & $15,2 \%$ & $19,6 \%$ & $13,0 \%$ & $100,0 \%$ \\
\hline \multirow{2}{*}{\multicolumn{2}{|c|}{ Toplam }} & 689 & 396 & 63 & 40 & 53 & 125 & 126 & 39 & 1531 \\
\hline & & $45,0 \%$ & $25,9 \%$ & $4,1 \%$ & $2,6 \%$ & $3,5 \%$ & $8,2 \%$ & $8,2 \%$ & $2,5 \%$ & $100,0 \%$ \\
\hline
\end{tabular}

Katılımcıların hayat tarzı ile siyasi kimlik tanımlamaları arasındaki ilişkiden tablodan da görüldüğ̈ üzere dindar muhafazakâr ve geleneksel muhafazakâr hayat tarzı benimseyenlerin önemli bir bölümü $(\% 58,8)$ siyasal kimlik olarak da muhafazakâr kimlik üzerinden kendilerini tanımlamaktadırlar. Öte yandan tablo içerisinde bahsi geçen bütün hayat tarzlarında milliyetçi bir siyasi kimlik üzerinden de kendini tanımlayanların oranı \%16 ile \%34 arasında değişmektedir. Geleneksel muhafazakâr hayat tarzını benimseyenlerin Atatürkçü siyasi kimliği \% 1,9 iken; modern hayat tarzını benimseyenlerin Atatürkçü siyasi kimliği üzerinden kendini tanımlama oranı ise $\% 21.4$ olarak görülmektedir.

Tablo 12: Katılımcılara Göre Siyasi Görüş̧e Sahip Olmanın Önemsenmesi

\begin{tabular}{|l|c|c|}
\hline \multicolumn{2}{|c|}{$\begin{array}{c}\text { Sizce bir siyasal görüsse/kimliğe sahip } \\
\text { olmak gerekir mi? }\end{array}$} \\
\hline & $\mathrm{F}$ & $\%$ \\
\hline Evet & 849 & 55,5 \\
\hline Hayır & 682 & 44,5 \\
\hline Toplam & 1531 & 100,0 \\
\hline
\end{tabular}

Siyasal görüşler oy kullanan seçmenler ve siyaset üreten politikacılar nazarında önemli bir yere tekabül etmektedir. Çünkü kamuoyunu etkileme, yönlendirme ve toplumsal manada bir etki oluşturmanın önemli unsurlarından biri de siyasal görüş/siyasal kimliklerdir. Katılımcıların yarıdan fazlası $(\% 55,5)$ bir siyasal görüş̧e/ kimliğe sahip olmayı önemsemektedir. Katılımcıların \%44.5'i ise siyasi bir görüşe, siyasi bir kimliğe sahip olmanın gerekli olmadı̆̆ını belirtmişlerdir.

Tablo 13: Hayat Tarzına Göre Siyasi Görüşe Sahip Olma Düşüncesi

\begin{tabular}{|c|c|c|c|c|}
\hline \multirow{2}{*}{\multicolumn{2}{|c|}{$\chi^{2}=27,261 ; \mathrm{sd}: 3 ; \mathrm{p}:, 000$}} & \multicolumn{2}{|c|}{$\begin{array}{c}\text { Sizce bir siyasal görüsşe/kimliğe } \\
\text { sahip olmak gerekir mi? }\end{array}$} & \multirow{3}{*}{$\begin{array}{l}\text { Toplam } \\
100,0 \% \\
\end{array}$} \\
\hline & & \multirow{2}{*}{$\begin{array}{c}\text { Evet } \\
46,8 \%\end{array}$} & \multirow{2}{*}{$\begin{array}{l}\text { Hayır } \\
53,2 \%\end{array}$} & \\
\hline \multirow{4}{*}{$\underset{\mathbb{E}}{\mathbb{4}}$} & Modern & & & \\
\hline & Geleneksel Muhafazakâr & $54,3 \%$ & $45,7 \%$ & $100,0 \%$ \\
\hline & Dindar Muhafazakâr & $69,6 \%$ & $30,4 \%$ & $100,0 \%$ \\
\hline & Diğer & $39,1 \%$ & $60,9 \%$ & $100,0 \%$ \\
\hline \multicolumn{2}{|c|}{ Toplam } & $55,5 \%$ & $44,5 \%$ & $100,0 \%$ \\
\hline
\end{tabular}

Hayat tarzı ile siyasi bir görüşe sahip olma düşüncesi arasında anlamlı bir ilişki olduğu belirlenmiştir. Buna göre, Modernler diğer hayat tarzlarına göre daha düşük (\%46.8) düzeyde siyasi bir görüşe sahip olunmas1 gerektiğini düşünmektedir. Geleneksel Muhafazakârların \%54.3'ü, dindar Dindar Muhafazakârların ise \%69.6's1 siyasi bir görüşe sahip olunması gerektiğini düşünmektedir. 
Tablo 14: Siyasi Kimliğe Göre Siyasi Görüşe Sahip Olma Düşüncesi

\begin{tabular}{|c|c|c|c|c|}
\hline \multirow{2}{*}{\multicolumn{2}{|c|}{$\begin{array}{l}\chi^{2}=28,721 ; \mathrm{sd}: 7 ; \mathrm{p}: \\
, 000\end{array}$}} & \multicolumn{2}{|c|}{$\begin{array}{c}\text { Sizce bir siyasal görüsşe/kimliğe } \\
\text { sahip olmak gerekir mi? }\end{array}$} & \multirow[t]{2}{*}{ Toplam } \\
\hline & & Evet & Hayır & \\
\hline \multirow{16}{*}{ 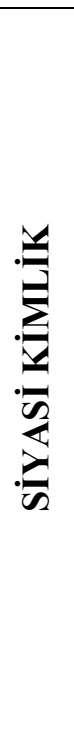 } & \multirow{2}{*}{ Muhafazakâr } & 368 & 321 & 689 \\
\hline & & $53,4 \%$ & $46,6 \%$ & $100,0 \%$ \\
\hline & \multirow[t]{2}{*}{ Milliyetçi } & 237 & 159 & 396 \\
\hline & & $59,8 \%$ & $40,2 \%$ & $100,0 \%$ \\
\hline & \multirow[t]{2}{*}{ Demokrat } & 39 & 24 & 63 \\
\hline & & $61,9 \%$ & $38,1 \%$ & $100,0 \%$ \\
\hline & \multirow{2}{*}{$\begin{array}{l}\text { Sosyal } \\
\text { Demokrat }\end{array}$} & 25 & 15 & 40 \\
\hline & & $62,5 \%$ & $37,5 \%$ & $100,0 \%$ \\
\hline & \multirow[t]{2}{*}{ Sosyalist } & 24 & 29 & 53 \\
\hline & & $45,3 \%$ & $54,7 \%$ & $100,0 \%$ \\
\hline & \multirow[t]{2}{*}{ Atatürkçü } & 61 & 64 & 125 \\
\hline & & $48,8 \%$ & $51,2 \%$ & $100,0 \%$ \\
\hline & \multirow[t]{2}{*}{ İslamc1 } & 84 & 42 & 126 \\
\hline & & $66,7 \%$ & $33,3 \%$ & $100,0 \%$ \\
\hline & \multirow[t]{2}{*}{ Diğer } & 11 & 28 & 39 \\
\hline & & $28,2 \%$ & $71,8 \%$ & $100,0 \%$ \\
\hline
\end{tabular}

Siyasal görüşler genellikle siyasal kimliklerin etki alanında şekillenir. Tabloya göre bir siyasal görüşe sahip olmanın en çok etkin olduğu siyasal kimlikler sırasıyla; \% 66,7 İslamcı, \% 62,5 Sosyal demokrat,\% 61,9 ile demokratlar arasında daha çok önemsenmektedir. Dolayısıyla seçmenlerin siyasi kimlikleri ile siyasal görüşe/ kimliğe sahip olma gerekliliği arasında anlamlı bir ilişki olduğu belirlenmiştir.

Tablo 15: Siyasi Tercihe Göre Siyasi Görüşe Sahip Olma Düşüncesi

\begin{tabular}{|c|c|c|c|c|}
\hline \multirow{2}{*}{\multicolumn{2}{|c|}{$\chi^{2}=21,968 ;$ sd:8 p:, 000}} & \multicolumn{2}{|c|}{$\begin{array}{l}\text { Sizce bir siyasal görüsşe/kimliğe } \\
\text { sahip olmak gerekir mi? }\end{array}$} & \multirow{3}{*}{$\begin{array}{l}\text { Toplam } \\
100.0 \%\end{array}$} \\
\hline & & Evet & Hayır & \\
\hline \multirow{9}{*}{ 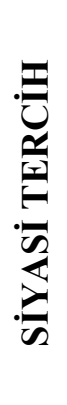 } & AK Parti & $59,2 \%$ & $40,8 \%$ & \\
\hline & CHP & $51,2 \%$ & $48,8 \%$ & $100,0 \%$ \\
\hline & MHP & $53,6 \%$ & $46,4 \%$ & $100,0 \%$ \\
\hline & HDP & $60,0 \%$ & $40,0 \%$ & $100,0 \%$ \\
\hline & Saadet Partisi & $55,0 \%$ & $45,0 \%$ & $100,0 \%$ \\
\hline & IYYI Parti & $63,3 \%$ & $36,7 \%$ & $100,0 \%$ \\
\hline & Diğer & $50,0 \%$ & $50,0 \%$ & $100,0 \%$ \\
\hline & Oy Kullanmadım & $21,0 \%$ & $79,0 \%$ & $100,0 \%$ \\
\hline & Cevap Yok & $45,6 \%$ & $54,4 \%$ & $100,0 \%$ \\
\hline & Toplam & $55,5 \%$ & $44,5 \%$ & $100,0 \%$ \\
\hline
\end{tabular}

Siyasi tercih ile siyasal bir görüşe sahip olma gerekliliği arasındaki ilişkiyi ortaya koyan tabloya göre her siyasi partiyi tercih edenler belirli oranlarda bir siyasi görüşe sahip olma gerekliliğini ifade etmişlerdir. Ancak, IYYİ Parti, AK Parti, ve Saadet Partisi seçmeni diğer seçmen gruplara göre kısmen de olsa daha yüksek oranda bir siyasi görüşe sahip olma gerekliliği beyanında bulunmuşlardır.

\section{Tablo 16: Genel Ve Yerel Seçimlerde Oy Kullanma Sıklığı}

\begin{tabular}{|l|c|c|}
\hline & F & $\%$ \\
\hline Her seçimde & 1213 & 79,2 \\
\hline Bazen & 267 & 17,4 \\
\hline Hiç oy kullanmam & 51 & 3,3 \\
\hline Toplam & 1531 & 100,0 \\
\hline
\end{tabular}

Bir siyasi görüşe sahip olma ve bu görüşlerin karşılığı olan bir siyasi parti tercihi yapmak seçmenler için siyasal tercihlerinin yerel ve ulusal yönetime yansımasındaki kararlılıklarının bir göstergesi olarak değerlendirilmektedir. Bu davranış sıklığı aynı zamanda seçmenin bir siyasal görüşe sahip olma konusundaki 
duruşunu da ön plana çıkartmaktadır. Bunun yanı sıra yerel belediyelerin ve merkezi hükümetin performansı, alternatifler, seçmenlerin oy kullanma sıklıklarına etki eden diğer faktörler arasında yer almaktadır.

Katılımcıların \%79,2'si her seçimde oy kullandığını ifade ederken, \%17.4'ü bazen oy kullandığını ifade etmiştir. Katılımcıların \%3.3^ü ise hiçbir zaman oy kullanmadıklarını dile getirmişlerdir. Buna göre, Malatya siyasal katılımın önemli bir göstergesi olan seçimlere katılım oranının oldukça yüksek olduğu görülmektedir.

Tablo 17: Hayat Tarzına Göre Genel ve Yerel Seçimlerde Oy Kullanma Sıklığı

\begin{tabular}{|l|l|c|c|c|c|}
\hline \multirow{2}{*}{$\begin{array}{l}\chi^{2}=18,633 ; \text { sd:6; } 0: \\
005\end{array}$} & \multicolumn{3}{|c|}{$\begin{array}{c}\text { "Genel ve yerel seçimlerde ne sıklıkla } \\
\text { oy kullanırsını? }\end{array}$} & Toplam \\
\cline { 3 - 6 } & $\begin{array}{l}\text { Her } \\
\text { Seçimde }\end{array}$ & Bazen & $\begin{array}{c}\text { Hiç Oy } \\
\text { Kullanmam }\end{array}$ & \\
\hline \multirow{3}{*}{} & Modern & $82,0 \%$ & $14,0 \%$ & $4,0 \%$ & $100,0 \%$ \\
\cline { 2 - 6 } & $\begin{array}{l}\text { Geleneksel } \\
\text { Muhafazakâr }\end{array}$ & $77,2 \%$ & $20,5 \%$ & $2,2 \%$ & $100,0 \%$ \\
\cline { 2 - 6 } & $\begin{array}{l}\text { Dindar- } \\
\text { Muhafazakâr }\end{array}$ & $79,8 \%$ & $17,0 \%$ & $3,2 \%$ & $100,0 \%$ \\
\cline { 2 - 6 } & Diğer & $69,6 \%$ & $19,6 \%$ & $10,9 \%$ & $100,0 \%$ \\
\hline \multicolumn{2}{|l|}{ Toplam } & $79,2 \%$ & $17,4 \%$ & $3,3 \%$ & $100,0 \%$ \\
\hline
\end{tabular}

Katılımcıların hayat tarzı ile seçimlerde oy kullanma sıklığı arasındaki ilişkiyi ortaya koyan tabloda da görüldüğü üzere modern hayat tarzına sahip olanlar diğerlerine göre daha yüksek oranda her seçimde oy kullanmaktadır. Bu durum demokrasiye olan inançtan kaynaklı olarak değerlendirilmektedir.

Siyasi kimlik ile oy kullanma sıklığı arasındaki ilişki analiz edildiğinde bu durum daha net olarak ortaya çıkmaktadır. Siyasi kimlik olarak kendilerini demokrat olarak tanımlayanların \% 92,1'si; sosyal demokratların \%85.0'1, muhafazakârların ise \%77.8'i her seçimde her genel ve yerel seçimlerde sandık başına gitmektedir.

Siyasal kimlik olarak kendini Demokrat olarak tanımlayanların \%92.1'i, Atatürkçü olarak tanımlayanların \%86.4'ü, Sosyal demokrat olarak tanımlayanların \%85.0'ı her seçimde oy kullandığını ifade etmektedirler. Hayat tarzı bakımından kendini modern olarak tanımlayanlar da ifade edildiği üzere bu durumum demokrasi inancı ve kültürüyle ilgili olduğu düşünülmektedir.

Tablo 18: Katılımcıların Çocuklarının Kendi Siyasi Görüşünü Paylaşma Düşüncesi

\begin{tabular}{|l|c|c|}
\hline \multicolumn{3}{|c|}{$\begin{array}{c}\text { Çocuklarınızın Kendi Siyasi Görüşünüzü Paylaşmasını } \\
\text { İster misiniz? }\end{array}$} \\
\hline & $\mathrm{F}$ & $\%$ \\
\hline Evet-kesinlikle & 679 & 44,4 \\
\hline Fark etmez-kendi tercihi & 759 & 49,6 \\
\hline Hayır & 93 & 6,1 \\
\hline Toplam & 1531 & 100,0 \\
\hline
\end{tabular}

Siyasal karar verme süreçlerinde bireylerin en çok etkilendiği ve buna göre de bir davranış sergilediği sosyo-politik düşüncenin somutlaştığı yer ailedir. Aile, çocukların bir siyasal partiye karşı duygusal bir bağ geliştirmesinin temelinde yatan bir etkendir. Kimi araştırmacılara göre, çocukların siyasal toplumsallaşma sürecinde, siyasal parti kimliğinin aşılanmasında, aile en büyük faktördür. Ailede anne-baba-çocuk arasında siyasal bilgi alışverişinin olması, çocukların küçük yaşta bir siyasal parti seçmelerinin yanında, seçilen partinin anne-babanın desteklediği siyasal parti olma olasılığını da artırmaktadır (Karakoç, 2000: 39).

Easton ve Dennis, çocukların siyasi sosyalleşmesinin dört aşamadan geçtiğini ifade etmektedirler. Bunlardan birincisi, "siyasallaşma aşamasıı"dır. Bu aşamada çocuk ailesi dışında siyasi bir alanın varlığının farkına varır. İkinci aşama olan "kişiselleştirme aşaması"nda ise çocuk için başkan ve polis iki ideal otorite ve makamlardır. Üçüncü aşamada "genelleme aşaması"dır ki, bu aşamada çocuk ideal otorite sahiplerini idealize eder, siyasal meşrulaştırma genelleştirilir. Son aşama ise "kurumsallaştırma aşaması"dır. Bu aşamada, kişiselleştirilmiş yapılardan kurumlara yön değiştirilmesi gerçekleşir (Sears, 1971: 155).

Aile, uyguladığı bilinçli toplumsallaşma süreci ile çocuğa toplumsal değer ve normları olduğu kadar, aile içi somut ilişkilerle de belli karar verme kalıplarını aktarmaktadır. Bu nedenle aile hem seçme işlemini, hem de davranışın temelini veren bir öğe olarak sosyo-politik bir önem taşımaktadır (Uysal, 1981: 115-116.). Değişen toplumsal yapımızla birlikte toplumsal bakış açılarında da değişimlerin olması kaçınılmazdır. Bu değişim ailenin de daha demokratik bir yapıya kavuşmasını etkilemiştir. Aile içi demokrasinin önemli göstergelerinden biri de ebeveynler ile çocukların siyasal görüşü paylaşımına ilişkin değerlendirmelerdir. 
Tabloda da görüldüğü üzere katılımcıların \%44.4'ü çocuklarının kendi siyasi görüşünü paylaşmasını isterken; \%49.6'sı ise fark etmez değerlendirmesinde bulunmuştur. Katılımcıların \%6.1'i ise çocuklarının kendi siyasi görüşünü paylaşmasını istemediklerini belirtmişlerdir.

\section{Tablo 19: Hayat Tarzına Göre Çocuklarının Kendi Siyasi Görüşünü Paylaşma Düşüncesi}

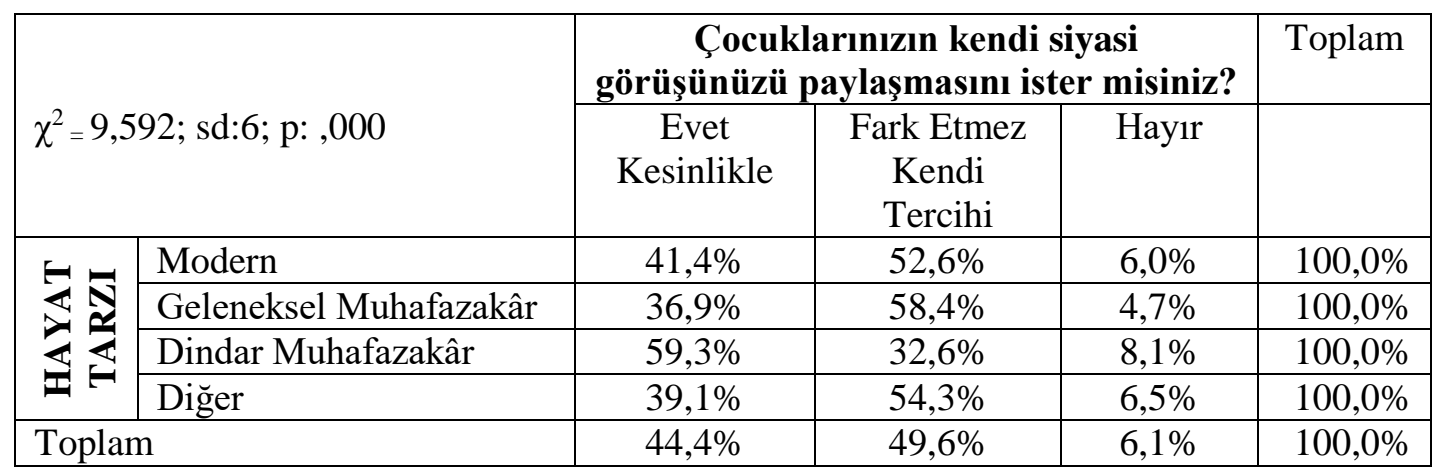

Katılımcılara yöneltilen "çocuklarınızın kendi siyasi görüşünüze sahip olmasını ister misiniz? sorusuna hayat tarzına göre farklı beyanlarda bulunulmuştur. Dindar Muhafazakârlar \%59.3 oranında evet kesinlikle cevabı verirken, geleneksel muhafazakârlar ise \%58.4 oranında fark etmez kendi tercihi değerlendirmesinde bulunmuşlardır.

Tablo 20: Siyasi Kimliğe Göre Çocuklarının Kendi Siyasi Görüşünü Paylaşma Düşüncesi

\begin{tabular}{|c|c|c|c|c|c|}
\hline \multirow{2}{*}{\multicolumn{2}{|c|}{$\chi^{2}=32,014 ; \mathrm{sd}: 14 ; \mathrm{p}: 0,004$}} & \multicolumn{3}{|c|}{$\begin{array}{l}\text { Çocuklarınızın kendi siyasi } \\
\text { görüşününzü paylaşmasını ister } \\
\text { misiniz? }\end{array}$} & \multirow{3}{*}{$\begin{array}{c}\text { Toplam } \\
\\
689\end{array}$} \\
\hline & & \multirow{2}{*}{$\begin{array}{c}\begin{array}{c}\text { Evet } \\
\text { Kesinlikle }\end{array} \\
311 \\
\end{array}$} & \multirow{2}{*}{$\begin{array}{c}\text { Fark Etmez } \\
\text { Kendi Tercihi } \\
344\end{array}$} & \multirow{2}{*}{$\begin{array}{c}\text { Hayır } \\
34\end{array}$} & \\
\hline \multirow{16}{*}{ 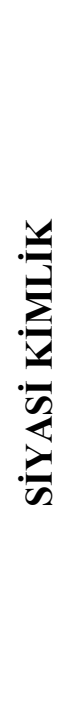 } & \multirow[t]{2}{*}{ Muhafazakâr } & & & & \\
\hline & & $45,1 \%$ & $49,9 \%$ & $4,9 \%$ & $100,0 \%$ \\
\hline & \multirow[t]{2}{*}{ Milliyetçi } & 168 & 206 & 22 & 396 \\
\hline & & $42,4 \%$ & $52,0 \%$ & $5,6 \%$ & $100,0 \%$ \\
\hline & \multirow[t]{2}{*}{ Demokrat } & 26 & 32 & 5 & 63 \\
\hline & & $41,3 \%$ & $50,8 \%$ & $7,9 \%$ & $100,0 \%$ \\
\hline & \multirow{2}{*}{$\begin{array}{l}\text { Sosyal } \\
\text { Demokrat }\end{array}$} & 16 & 21 & 3 & 40 \\
\hline & & $40,0 \%$ & $52,5 \%$ & $7,5 \%$ & $100,0 \%$ \\
\hline & \multirow[t]{2}{*}{ Sosyalist } & 25 & 26 & 2 & 53 \\
\hline & & $47,2 \%$ & $49,1 \%$ & $3,8 \%$ & $100,0 \%$ \\
\hline & \multirow[t]{2}{*}{ Atatürkçü } & 49 & 67 & 9 & 125 \\
\hline & & $39,2 \%$ & $53,6 \%$ & $7,2 \%$ & $100,0 \%$ \\
\hline & \multirow[t]{2}{*}{ İslamc1 } & 74 & 38 & 14 & 126 \\
\hline & & $58,7 \%$ & $30,2 \%$ & $11,1 \%$ & $100,0 \%$ \\
\hline & \multirow[t]{2}{*}{ Diğer } & 10 & 25 & 4 & 39 \\
\hline & & $25,6 \%$ & $64,1 \%$ & $10,3 \%$ & $100,0 \%$ \\
\hline \multirow{2}{*}{\multicolumn{2}{|c|}{ Toplam }} & 679 & 759 & 93 & 1531 \\
\hline & & $44,4 \%$ & $49,6 \%$ & $6,1 \%$ & $100,0 \%$ \\
\hline
\end{tabular}

Seçmenlerin siyasi kimlikleri ile çocuklarının kendi siyasi görüşlerini paylaşma düşüncesi arasındaki ilişkiyi ortaya koyan tabloya göre siyasal kimlik olarak İslamcıların \% 58,7'si, Sosyalistlerin \%47.2'si, Muhafazakârların \% 45,1'i çocuklarının kendi siyasi görüşlerini paylaşması düşüncesi taşımaktadırlar. Diğer yandan Atatürkçülerin \%53.6's1, sosyal demokratların \%52.5'i, Milliyetçilerin \%52.0'1, Demokratların $\% 50.8$ 'i ise fark etmez kendi tercihi değerlendirmesinde bulunmuşlardır. 
Tablo 21: Siyasi Tercihe Göre Çocuklarının Kendi Siyasi Görüşünü Paylaşma Düşüncesi

\begin{tabular}{|c|c|c|c|c|c|}
\hline \multirow{2}{*}{\multicolumn{2}{|c|}{$\begin{array}{l}\chi^{2}=17,773 ; \mathrm{sd}: 16 \\
\mathrm{p}: 0,000\end{array}$}} & \multicolumn{3}{|c|}{$\begin{array}{l}\text { Çocuklarınızın kendi siyasi } \\
\text { görüşünüzü paylaşmasını ister } \\
\text { misiniz? }\end{array}$} & \multirow{3}{*}{$\begin{array}{l}\text { Toplam } \\
100,0 \%\end{array}$} \\
\hline & & \multirow{2}{*}{$\begin{array}{c}\begin{array}{c}\text { Evet } \\
\text { Kesinlikle }\end{array} \\
46,4 \%\end{array}$} & \multirow{2}{*}{$\begin{array}{c}\text { Fark etmez } \\
\text { Kendi Tercihi } \\
47,9 \%\end{array}$} & \multirow{2}{*}{$\begin{array}{l}\text { Hayır } \\
5,7 \%\end{array}$} & \\
\hline \multirow{9}{*}{ 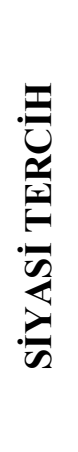 } & AK Parti & & & & \\
\hline & CHP & $45,9 \%$ & $47,6 \%$ & $6,5 \%$ & $100,0 \%$ \\
\hline & MHP & $45,9 \%$ & $50,9 \%$ & $3,2 \%$ & $100,0 \%$ \\
\hline & HDP & $37,1 \%$ & $51,4 \%$ & $11,4 \%$ & $100,0 \%$ \\
\hline & Saadet Partisi & $45,0 \%$ & $55,0 \%$ & & $100,0 \%$ \\
\hline & İYI Parti & $43,3 \%$ & $46,7 \%$ & $10,0 \%$ & $100,0 \%$ \\
\hline & Diğer & $50,0 \%$ & $50,0 \%$ & & $100,0 \%$ \\
\hline & $\begin{array}{l}\text { Oy } \\
\text { Kullanmadım }\end{array}$ & $14,5 \%$ & $67,7 \%$ & $17,7 \%$ & $100,0 \%$ \\
\hline & Cevap Yok & $36,8 \%$ & $56,1 \%$ & $7,0 \%$ & $100,0 \%$ \\
\hline \multicolumn{2}{|c|}{ Toplam } & $44,4 \%$ & $49,6 \%$ & $6,1 \%$ & $100,0 \%$ \\
\hline
\end{tabular}

Katılıcıların siyasi tercihi ile çocuklarının kendi siyasi görüşlerini paylaşma düşüncesi arasında anlamlı bir ilişki belirlenmiştir. AK Parti seçmeni diğer partilere göre daha yüksek oranda çocuklarının da kendi siyasi görüşünde olmalarını isterken, Saadet Partisi seçmeni ise diğer parti seçmenlerine göre daha yüksek oranda fark etmez kendi tercihi değerlendirmesinde bulunmuştur.

Tablo 22: Katılımcıların Çocuğu Farklı Bir Siyasi Görüş̧e Sahip Olması Durumunda Tavrı

\begin{tabular}{|l|c|c|}
\hline & F & $\%$ \\
\hline Kesinlikle Karışmam & 784 & 51,2 \\
\hline Değiştirmesini İsterim Ama Zorlamam & 606 & 39,6 \\
\hline Değiştirmesi İçin Zorlarım & 133 & 8,7 \\
\hline Diğer & 8 &, 5 \\
\hline Toplam & 1531 & 100,0 \\
\hline
\end{tabular}

Siyasal sosyalleşme sürecinde ailenin yanı sıra okul, sivil toplum kuruluşları, arkadaşlar ve kitle iletişim araçları gibi farklı araçlar etkili olmaktadır. Bu araçların da etkisiyle aile ile çocukların görüşü farklılık gösterebilmektedir. Bu kapsamda katılımcılara çocuklarının siyasi görüşlerinin kendi siyasi görüşlerinden farklı olması durumunda ne tür bir tavır ortaya koydukları sorulmuştur. Buna göre katılımcıların \%51.2'si kesinlikle karışmam demiştir. Buna karşın katılımcıların \%39.6'1 ise "değiştirmesini isterim ama zorlamam" değerlendirmesinde bulunmuştur. Katılımcıların \%8.7'si ise "değiştirmesi için zorlarım" beyanında bulunmuştur.

Tablo 23: Hayat Tarzına Göre Çocuğu Farklı Bir Siyasi Görüşe Sahip Olması Durumunda Tavrı

\begin{tabular}{|l|l|c|c|c|c|c|}
\hline \multicolumn{2}{|l|}{$\begin{array}{l}\chi^{2}=198,308 ; \text { sd:9; p: } \\
, 000\end{array}$} & \multicolumn{3}{|c|}{ Çocuğunuz farklı bir siyasi görüşe sahip olsa ne } & Toplam \\
\cline { 2 - 7 } & $\begin{array}{c}\text { Kesinlikle } \\
\text { Karışmam }\end{array}$ & $\begin{array}{c}\text { Değiştirmesini } \\
\text { İsterim Ama } \\
\text { Zorlamam }\end{array}$ & $\begin{array}{c}\text { Değiştirmesi } \\
\text { İçin } \\
\text { Zorlarım }\end{array}$ & Diğer & \\
\hline \multirow{3}{*}{} & Modern & $64,8 \%$ & $28,4 \%$ & $6,6 \%$ &, $2 \%$ & $100,0 \%$ \\
\cline { 2 - 7 } & $\begin{array}{l}\text { Geleneksel } \\
\text { Muhafazakâr }\end{array}$ & $49,5 \%$ & $43,1 \%$ & $7,1 \%$ &, $3 \%$ & $100,0 \%$ \\
\cline { 2 - 7 } & $\begin{array}{l}\text { Dindar } \\
\text { Muhafazakâr }\end{array}$ & $36,0 \%$ & $49,4 \%$ & $13,6 \%$ & $1,0 \%$ & $100,0 \%$ \\
\cline { 2 - 7 } & Diğer & $58,7 \%$ & $30,4 \%$ & $8,7 \%$ & $2,2 \%$ & $100,0 \%$ \\
\hline \multicolumn{2}{|l|}{ Toplam } & $51,2 \%$ & $39,6 \%$ & $8,7 \%$ &, $5 \%$ & $100,0 \%$ \\
\hline
\end{tabular}

Katılımcıların hayat tarzı ile göre çocuğu farklı bir siyasi görüşe sahip olması durumunda takınılan tavır arasında anlamlı bir ilişki vardır. Kendini modern olarak tanımlayan katılımcıların \%64.8'i çocuğuma karışmam derken, geleneksel muhafazakârların \%49.5'i, dindar muhafazakârların \%36.'sı “çocuğuma karışmam" değerlendirmesinde bulunmuştur. Dindar muhafazakârların \%13.6'sının değiştirmesi için zorlarım 
yönündeki beyanları ise dikkat çekmektedir. Bu anlamda modern hayat tarzınsa sahip olduğunu düşünenlerin diğerlerin göre daha çocuklarının siyasi görüşünü değiştirmesi yönünde bir tavır içerisine girmeme eğilimlerinin daha yüksek oranda olduğu belirlenmiştir.

Tablo 24: Katılımcıların Farklı Bir Siyasi Görüşü Olduğunu Bildiği Yerden Alış Veriş Yapma Durumu

\begin{tabular}{|l|c|c|}
\hline \multicolumn{3}{|c|}{$\begin{array}{c}\text { Farklı bir siyasi görüşü olduğunu bildiğiniz bir } \\
\text { yerden alış veriş yapar mısını? }\end{array}$} \\
\hline & $\mathrm{F}$ & $\%$ \\
\hline Evet kesinlikle & 334 & 21,8 \\
\hline Fark etmez & 1027 & 67,1 \\
\hline Hayır & 170 & 11,1 \\
\hline Toplam & 1531 & 100,0 \\
\hline
\end{tabular}

Siyasal görüş bireylerin gündelik yaşamda bireylerin çeşitli davranışlarını etkileyebilmektedir. Bu anlamda bireylerin tüketici olarak davranışlarında etkili olan faktörlerden biri de siyasal görüş olabilmektedir. Katılımcıların, \%21.8'i ise farklı bir siyasi görüşü olduğunu bildiği yerden alış veriş yapacağını güçlü bir şekilde ifade ederken, katılımcıların \%67.1' $\mathrm{i}$ ise fark etmez değerlendirmesinde bulunmuştur. Katılımcıların, \%11.1'i ise farklı bir siyasi görüşü olduğunu bildiği yerden alış veriş yapmayacağını belirtmiştir. Siyasi görüşünün alışveriş yapma konusunda belirleyici olmadığını söyleyebiliriz. Çünkü farklı bir siyasi görüşü olan yerde alışveriş yaparım diyenlerin oranı ki buna fark etmez diyenleri de eklediğimizde \%88,9'a (1361 kişi) tekabül etmektedir.

Tablo 25: Siyasi Kimliğe Göre Farklı Bir Siyasi Görüşü Olduğunu Bildiği Yerden Alış Veriş Yapma Durumu

\begin{tabular}{|c|c|c|c|c|c|}
\hline \multirow{2}{*}{\multicolumn{2}{|c|}{$\begin{array}{l}\chi^{2}=96,871 ; \mathrm{sd}: 14 ; \mathrm{p}: \\
, 000\end{array}$}} & \multicolumn{3}{|c|}{$\begin{array}{l}\text { Farklı bir siyasi görüşü } \\
\text { olduğunu bildiğiniz bir yerden } \\
\text { alış veriş yapar mısınız? }\end{array}$} & \multirow[t]{2}{*}{ Toplam } \\
\hline & & $\begin{array}{c}\text { Evet } \\
\text { Kesinlikle }\end{array}$ & $\begin{array}{c}\text { Fark } \\
\text { Etmez }\end{array}$ & Hayır & \\
\hline \multirow{16}{*}{$\frac{\sqrt{3}}{\sum^{3}}$} & \multirow[t]{2}{*}{ Muhafazakâr } & 136 & 485 & 68 & 689 \\
\hline & & $19,7 \%$ & $70,4 \%$ & $9,9 \%$ & $100,0 \%$ \\
\hline & \multirow[t]{2}{*}{ Milliyetçi } & 80 & 271 & 45 & 396 \\
\hline & & $20,2 \%$ & $68,4 \%$ & $11,4 \%$ & $100,0 \%$ \\
\hline & \multirow[t]{2}{*}{ Demokrat } & 23 & 36 & 4 & 63 \\
\hline & & $36,5 \%$ & $57,1 \%$ & $6,3 \%$ & $100,0 \%$ \\
\hline & \multirow{2}{*}{$\begin{array}{l}\text { Sosyal } \\
\text { Demokrat }\end{array}$} & 13 & 22 & 5 & 40 \\
\hline & & $32,5 \%$ & $55,0 \%$ & $12,5 \%$ & $100,0 \%$ \\
\hline & \multirow[t]{2}{*}{ Sosyalist } & 28 & 24 & 1 & 53 \\
\hline & & $52,8 \%$ & $45,3 \%$ & $1,9 \%$ & $100,0 \%$ \\
\hline & \multirow[t]{2}{*}{ Atatürkçü } & 31 & 85 & 9 & 125 \\
\hline & & $24,8 \%$ & $68,0 \%$ & $7,2 \%$ & $100,0 \%$ \\
\hline & \multirow[t]{2}{*}{ İslamc1 } & 16 & 73 & 37 & 126 \\
\hline & & $12,7 \%$ & $57,9 \%$ & $29,4 \%$ & $100,0 \%$ \\
\hline & \multirow[t]{2}{*}{ Diğer } & 7 & 31 & 1 & 39 \\
\hline & & $17,9 \%$ & $79,5 \%$ & $2,6 \%$ & $100,0 \%$ \\
\hline \multirow{2}{*}{\multicolumn{2}{|c|}{ Toplam }} & 334 & 1027 & 170 & 1531 \\
\hline & & $21,8 \%$ & $67,1 \%$ & $11,1 \%$ & $100,0 \%$ \\
\hline
\end{tabular}

Siyasal kimlik ile farklı bir siyasi bir görüşe sahip olduğu bilinen alışveriş merkezi arasındaki ilişkiyi gösteren tabloya baktığımızda sosyalistlerin \%52,8'i, demokratların \%36.5'i yaparım değerlendirmesinde bulunurken, muhafazakarların \%70..4'ü, Milliyetçilerin \%68.4'ü, Atatürkçülerin \%68.0'1 fark etmez beyanında bulunmaktadırlar. İslamcıların \%29.4'ü, sosyal demokratların \%12.5'i, Milliyetçilerin ise \%11.4'ü hayır yapmam görüşündedirler. 
Tablo 26: Katılımcıların Sağ-Sol Kutuplaşmasında Kendini Gördükleri Yer

\begin{tabular}{|l|c|c|}
\hline \multicolumn{3}{|c|}{$\begin{array}{c}\text { Sağ-sol kutuplaşmasında kendinizi nerede } \\
\text { görüyorsunuz? }\end{array}$} \\
\hline & F & $\%$ \\
\hline Sağ & 921 & 60,2 \\
\hline Sol & 179 & 11,7 \\
\hline Merkez & 210 & 13,7 \\
\hline Hiçbiri & 221 & 14,4 \\
\hline Toplam & 1531 & 100,0 \\
\hline
\end{tabular}

Kutuplaşma kavramı disiplinler arasında birçok farklı tanımlama ile karşımıza çıkmaktadır. Toplumlar arasındaki diyalog mesafesinin aralığı kutuplaşmanın boyutlarının ortaya konulması açısından önemlidir. Kutuplaşma çoğunlukla bireylerin dâhil olduğu etnik, siyasi, dini vb. gruplara ait yaklaşımlar çerçevesinde ortaya çıktığı için, grup üzerinden oluşturulan kimliğin açıklanması kutuplaşmayı ve kutuplaşmanın sebeplerini anlamak için önemlidir. Siyasi kutuplaşmayı, hem partileşme hem bu partilerin yürüttüğü politikalar hem de bu politikaların vatandaşa yansıması olarak değerlendirmek gerekmektedir (Bilgiç, 2014: 167). Dolayısıyla kutuplaşma bireylerin siyasal kimliklerinin yansımasının bir göstergesi olarak değerlendirildiğinde sağ ve sol kavramlarının ideolojik boyutunun yanı sıra ilgili toplum içinde bireyin bir statüsü ve prestiji olarak da nitelendirilebilir. Bunların yanı sıra sağ ve sol ideoloji üzerinden kendilerini tanımlayanların seçmen-siyasal tercih-siyasal parti arasındaki iletişim boyutunu da şekillendirmektedir.

Araştırma kapsamında, katılımcıların \%60.2'si kendini sağ-sol kutuplaşmasında "sağ"da gördüğünü ifade ederken \%11.7'si ise "sol"da ifade etmektedir. Katılımciların \%13,7'si ise kendini merkez de tanımlamaktadır. Örneklem grubunun \%14.4'ü ise sağ-sol kutuplaşmasında hiçbir yerde kendini görmediğini beyan etmiştir.

Tablo 27: Hayat Tarzına Göre Sağ-Sol Kutuplaşmasında Kendini Gördükleri Yer

\begin{tabular}{|c|c|c|c|c|c|c|}
\hline \multicolumn{2}{|c|}{$\begin{array}{l}\chi^{2}=283,188 ; \mathrm{sd}: 9 ; \mathrm{p}: \\
, 000\end{array}$} & \multicolumn{4}{|c|}{$\begin{array}{l}\text { Sağ-sol kutuplaşmasında kendinizi } \\
\text { nerede görüyorsunuz? }\end{array}$} & \multirow{3}{*}{$\begin{array}{r}\text { Toplam } \\
500\end{array}$} \\
\hline & & Sağ & Sol & Merkez & Hiçbiri & \\
\hline \multirow{8}{*}{ 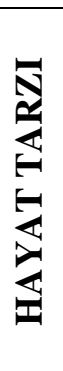 } & \multirow{2}{*}{ Modern } & 227 & 149 & 62 & 62 & \\
\hline & & $45,4 \%$ & $29,8 \%$ & $12,4 \%$ & $12,4 \%$ & $100,0 \%$ \\
\hline & \multirow{2}{*}{$\begin{array}{l}\text { Geleneksel } \\
\text { muhafazakâr }\end{array}$} & 366 & 21 & 90 & 103 & 580 \\
\hline & & $63,1 \%$ & $3,6 \%$ & $15,5 \%$ & $17,8 \%$ & $100,0 \%$ \\
\hline & \multirow{2}{*}{$\begin{array}{l}\text { Dindar- } \\
\text { muhafazakâr }\end{array}$} & 311 & 3 & 51 & 40 & 405 \\
\hline & & $76,8 \%$ & $0,7 \%$ & $12,6 \%$ & $9,9 \%$ & $100,0 \%$ \\
\hline & \multirow[t]{2}{*}{ Diğger } & 17 & 6 & 7 & 16 & 46 \\
\hline & & $37,0 \%$ & $13,0 \%$ & $15,2 \%$ & $34,8 \%$ & $100,0 \%$ \\
\hline \multirow{2}{*}{\multicolumn{2}{|c|}{ Toplam }} & 921 & 179 & 210 & 221 & 1531 \\
\hline & & $60,2 \%$ & $11,7 \%$ & $13,7 \%$ & $14,4 \%$ & $100,0 \%$ \\
\hline
\end{tabular}

Seçmenlerin hayat tarzı ile sağ-sol ideoloji arasındaki ilişki derecesini ortaya koyan tabloya göre modern hayat tarzını benimseyenlerin \% 45,4'ü sağ ideoloji, \%29,8'i ise sol ideolojiye yakın oldukları görülmektedir. Dindar muhafazakâr hayat tarzını benimseyenlerin ise \% 76,8'i sağ ideoloji, \% 13,0'ı da sol ideolojiye yakın oldukları gözlemlenmektedir. Geleneksel muhafazakârlar diğer hayat tarzlarına göre kendilerini daha fazla merkezde (\%15.5) görmektedirler.

\section{SONUÇ}

Siyasal kimlikler partiler üzerinden oluşturulup, siyasi partiler üzerinden işlevsel hale gelmektedir. $\mathrm{Bu}$ anlamda siyasal kimlik ve siyasal parti arasındaki diyalektik ilişkinin yansımasını doğal olarak siyasal tercihte de görmek mümkündür. Bireylerin yaşam tarzları da gündelik yaşam pratiklerini, çeşitli olaylara bakışlarını, siyasal kimliklerini ve siyasal tercihlerini de etkileyebilmektedir.

$\mathrm{Bu}$ çalışmada siyasal kimlik, yaşam tarzı ve siyasal tercih olguları Malatya ilinde yapılan bir araştırma ile çeşitli değiş̧kenler tarafından analiz edilmekte, bu olguların bir birileri ile ilişkileri de ortaya konulmaya çalışılmaktadır.

Elde edilen bulgulara göre, örneklem hayat tarzı bakımından modern, geleneksel muhafazakâr ve dindar muhafazakâr olarak sıralanmaktadır. Malatya bir Anadolu şehri olarak geleneksel değerler ile modern 
değerlerin birlikte yaşandığı kentlerden biri olması dolayısıyla geleneksel muhafazakârlık ile modernlik toplumun neredeyse dörtte üçünü oluşturmaktadır.

Hayat tarzı, kimliklerden etkilenen ama aynı zamanda kimlikleri de etkileyen bir olgu olmasının yanında gündelik pratiklere de etki etmektedir.

Hayat tarzı ile dini kimlik tanımlamaları arasındaki ilişki incelendiğinde modernler kendini daha yüksek oranda (\%69.2) Müslüman olarak tanımlarken, dindar muhafazakârlar kendilerini daha yüksek oranda (\%58.8) Sünni Müslüman olarak nitelendirmektedir.

Hayat tarzı ile siyasi kimlikler arasında diyalektik bir ilişki vardır. Sosyalleşme süreci her ikisini de etkilemekte her ikisi de bir birini etkilemektedir. Dindar muhafazakâr ve geleneksel muhafazakâr hayat tarzı benimseyenlerin önemli bir bölümü siyasal kimlik olarak da muhafazakâr kimlik üzerinden kendilerini tanımlarken modernler muhafazakâr, milliyetçi ve Atatürkçü şeklinde kimliklerle tanımlamaktadırlar.

Katılımcılar, siyasi bir görüşe sahip olma gerekliliği konusunda eşit düzeyde kanaate sahiptirler. Katılımcıların neredeyse yarısı bir siyasi görüşe sahip olmanın gerekliliğini ifade ederken diğer yarısı ise siyasi bir düşünceye sahip olmanın gerekli olmadığı düşüncesini taşımaktadırlar. Modern hayat tarzı ile kendini tanımlayanlar diğer hayat tarzlarına göre daha düşük oranda siyasi bir düşünceye sahip olma gerekliliğini belirtmişlerdir. Muhafazakârlık düzeyi artıkça siyasi bir görüşe sahip olma gerekliliğine olan inançta artmaktadır. Yine siyasi kimlik olarak kendin İslamcı olarak tanımlayanlar diğer kimliklere göre daha yüksek oranda siyasi bir düşünceye sahip olunması gerektiğini beyan etmişlerdir.

Katılımcıların çok önemli bir kısmı (\%79.2) her seçimde oy kullanırken, hayat tarzı bakımından da modernler diğerlerine göre daha yüksek oranda (\%82.0) her seçimde oy kullanmaktadırlar. Siyasi kimlik bağlamında ise kendini demokrat olarak tanımlayanlar diğer siyasi kimliklere göre daha yüksek oranda her seçimde oy kullanmaktadır.

Değişen toplumsal yapımızla birlikte toplumsal bakış açılarında da değişimlerin olması kaçınılmazdır. Bu değişim ailenin de daha demokratik bir yapıya kavuşmasını etkilemiştir. Aile içi demokrasinin önemli göstergelerinden biri de ebeveynler ile çocukların siyasal görüşü paylaşımına ilişkin değerlendirmelerdir. Katılımcıların yaklaşık olarak yarısı bu anlamda demokratik bir bakış açısıyla fark etmez değerlendirmesinde bulunmuşlardır. Hayat tarzı bakımından ise dindar muhafazakârlar, siyasi kimlik bağlamında ise kendini İslamcı olarak tanımlayanlar diğerlerine göre daha yüksek oranda çocuklarının kendi düşüncelerini paylaşmalarını arzu etmektedirler.

Katılımcıların çocuklarının siyasi görüşlerinin kendi siyasi görüşlerinden farklı olması durumunda takınacakları tavır da araştırma kapsamında analiz edilmiştir. Buna göre, oldukça sınırlı bir oranda katılımcı değiştirmesi için zorlamam değerlendirmesi yaparken katılımcıların önemli bir kısmı da karışmam, değiştirmesini isterim ama zorlamam görüşünü ifade etmişlerdir. Modern hayta tarzına sahip olanlar (\%64.8) diğer hayat tarzlarına göre çocuklarının siyasi görüşlerine karışmadıklarını beyan etmeleri kayda değer bir değerlendirme olarak belirlenmiştir.

Siyasal kimlik gündelik yaşam pratiklerini de etkiyebilmektedir. Araştırma kapsamında siyasal kimliğin tüketici davranışına etkisi de bir soru ile değerlendirmeye alınmıştır. Bu manada katılımcıların yaklaşık olarak \%90'ının alış veriş yaptıkları yerlerin siyasi görüşlerini değerlendirmeye almadıkları belirlenmiştir. Siyasi kimlik olarak kendini İslamcı olarak tanımlayanların bu konuda diğer kimliklere göre daha farklı bir bakış açısına sahip oldukları söylenebilir.

Sonuç olarak hayat tarzı ile siyasal kimlik tanımlamalarının bireylerin çeşitli tutum ve davranmışlarında etkilerinin analiz edildiği bu çalışmada modern hayat tarzına sahip olanlar geleneksel muhafazakâr ve dindar muhafazakârlara göre daha demokratik bir yaklaşım içerisinde oldukları söylenebilir. Hayat tarzı ve siyasal kimlik ile bireylerin çeşitli parametrelere bakışı arasında anlamlı ilişkiler vardır.

Siyasal kurumların ya da siyasal aktörlerin seçmenden bekledikleri desteği alabilmesi için seçmenin özelliklerini, eğilimlerini, beklentilerini, yaşam tarzlarını, kimlik tanımlamalarını derinlemesine analiz ederek, bu analizden elde edilen sonuçlar doğru bir mesaj planlaması yapması gereklidir.

Siyasal aktörlerin, seçim bölgelerinin sosyo demografik özellikleri yanında siyasal özelliklerini, hayat tarzlarını da dikkate alarak bir siyasal iletişim süreci işletmesi yerinde olacaktır. Seçmenini tüm özellikleriyle tanımak ve bu özellikler doğrultusunda bir iletişim kurmak siyasal aktörlerin başarısına katkı sağlayacak önemli bir unsur olacaktır. 


\section{KAYNAKLAR}

Altınoğlu, Mustafa, (2009) “Kimliklerin Modern İnşası, Kimlik Politikaları ve Türkiye'de Kimlik Doktora Tezi, Ankara.

Anderson, Benedict, (1993) Hayali Cemaatler -Milliyetçiliğin Kökenleri ve Yayılması, (Çev: İskender Başarır), Metis Yayınları, İstanbul.

Arnett, Jefrey. J. (1995). "Broad and Narrow Socialization: The Family in The Context of A Cultural Theory", Journal of Marriage and the Family, Vol.57, No.3, 617-628.

Aydoğdu, Hüseyin, (2004) “Modern Kimlikte Öznenin Ölümü”, Kazım Karabekir Eğitim Fakültesi Dergisi, $\quad$ S.10, 116-117.

Baykal, Deniz, (1970) Siyasal Katılma, bir Davranıs İncelemesi, Sevinç Matbaası, Ankara.

Bilgin, Nuri, (2007) Kimlik İnşası, Aşina Kitaplar, İzmir.

Bilgiç, Mehmet Sadi, (2014) “Türkiye’de Kimlikler Arası Kutuplaşmanın Sosyal Mesafe Üzerinden Ölçümü

Toplumsal Güvenliğe Etkisi”, Bilge Strateji, 6(11), 163-205.

Bostancı, Naci, (1998) "Etnisite, Modernizm ve Milliyetçilik”, Türkiye Günlüğü, S.50, 38-55.

Bozkurt, Veysel,(2004) "Yıkıc1 Gemenschaft"tan "Öteki"Siz Postmodern Kabilelere:SanalCemaatler", http://www.stradigma.com/nndex.php?1-11. Erişim Tarihi:14.03.2019.

Castells, Manue,l (2006) Enformasyon Çağı: Ekonomi, Toplum Ve Kültür Kimliğin Gücü (Ç.Ebru Kılıç), İstanbul Bilgi Üniversitesi Yayınları, İstanbul.

Doğan, Adem, (2014) Sosyal İlişkilerin Türk Seçmenin Siyasal Davranışına Etkisi, Fırat Üniversitesi Sosyal Bilimler Enstitüsü Yayımlanmamış Doktora Tezi, Elazı̆̆.

Dursun, Davut, (2012) Siyaset Bilimi, Beta Basım Yayım, İstanbul.

Ekinci, Necdet, (2008) Siyasal İletişime Giriş, Gece Kitaplığı, İstanbul.

Emiroğlu, Kudret, ve S, Aydın, (2003) Antropoloji Sözlüğ̈̈, Bilim ve Sanat Yayınları, Ankara.

Emre, Akif, (1999) Partisini Arayan Siyasal Kimlikler, https://www.yenisafak.com/yazarlar/akifemre /partisini-arayan-siyasal-kimlikler-41280,Erişim Tarihi:14.03.2019.

Erdoğan, İrfan, (2006) Kimlik Sorunu: Kendini Sevmeyenin Kimliğindeki Kendi Olmayan Kendi, Demokrasi Platformu -Üç Aylık Fikir-Kültür-Sanat ve Araştırma Dergisi, Dosya:Din, Kimlik, Kültür, Y:2, S: 5.

Ergun, Doğan, (2000) Kimlikler Kıskacında Ulusal Kişilik, İmge Yayınları, Ankara.

Göksu, Vahap, (2013) "Siyasal Kimlikler ve Merkez-Çevre Dikotomisi Bağlamında Türkiye'de Merkez Sağ

ve Merkez Sol", Akademik İncelemeler Dergisi, 8(2). 69-93.

Göktolga, Oğuzhan, (2012) Postmodernite ve Siyasal Kimlik, Bilsam Yayın, İstanbul.

Gülmen, Yüksel, (1979). Türk Seçmen Davranış1: 1960-1970, İstanbul Üniversitesi İktisat Fakültesi Yayınları (Güryay Yayınc1lik), İstanbul.

Gürses, Hakan, (2000) "Kimlik Kavramı Üzerine Düşünceler", Yeni Bir Sol Tahayyül İçin, (Der: Tanıl Bora), Birikim Yayınları, İstanbul.

Heidegger, Martin, (2008) Varlık ve Zaman, (çev. Kaan H. Ökten), Agora Kitaplığı, İstanbul.

Jensen, Mikael, (2007) Defining Lifestyle, Environmental Sciences, 4:2, 63-73.

Karakoç, İsmail, (2000) “Türkiye'de Siyasal Parti Kimliğì”, Yayınlanmamış Doktora Tezi, Dokuz Eylül Üniversitesi Sosyal Bilimler Enstitüsü, İzmir.

Karpat, Kemal, (2006) “Aydınlar ve Kimlik: Tarihsel Bir Bakış”, Doğu Batı Dergisi, Doğu Batı Yayınları, Y: 9, S:35, Ankara.

Konda, (2012) Siyasal Kimlikler Araştırması, http://konda.com.tr/tr/rapor/siyasal-kimlikler/, Erişim Tarihi:14.03.2019

Lipset, Seymour, M, (1967) Stein Rokkan, 'Cleavage Structures, Party Systems, and Voter Alignments: An Introduction', Party Systems and Voter Alignments: Cross-National Perspectives (Edit: Seymour M. Lipset, Stein Rokkan), The Free Pres, New York.

Maalouf, Amın, (2000) Ölümcül Kimlikler, (Çev.:Aysel Bora), YKY Yay., İstanbul.

Mardin, Şerif, (1990) Türkiye'de Toplum ve Siyaset Makaleleri, İletişim Yayınları, İstanbul.

Marshall, Gordon, (2003) Sosyoloji Sözlüğü (Çev: Osman Akınhay, Derya Kömürcü), Bilim ～ve Sanat Yayınları, Ankara.

Parmar, Priya, (1998) “Temsil Stratejileri”, Kimlik: Topluluk, Kültür, Farklılık, (Edit: Jonathan Rutherford), (Çev. İrem Sağlamer) Sarmal Yayınları, İstanbul.

Rob, Seiden, (2007) Parental Influences on the Political Ideologies of Young People, http://ase.tufts.edu/polsci/faculty/portney/studentSeiden.pdf, Erişim Tarihi:14.03.2019.

Rogers, M. Smith, (2004) Identities, Interests, and the Future of Political Science, Two Paths to a Science of Politics /Vol. 2/No. 2.

Rosengren, Karl Erik (1994) "Culture, Media And Society Agency And Structure, Continuity And Change", Media Effects and Beyond: Culture, Socialization and Lifestyles (Communication and Society), Ed. Karl Erik Rosengren, Routledge Published, New York, ABD, 2-24

Rutherford, Jonathan, (1998) "Yuva Denilen Yer: Kimlik ve Farklılığın Kültürel Politikaları”, Kimlik:Topluluk, Kültür, Farklılık, (Edit: Jonathan Rutherford), (Çev. İrem Sağlamer), Sarmal Yayınları, İstanbul. 
Sears, David O. (1971) Children in the Political System: Origins of Political Legitimacy. Midwest Journal of Political Science, Vol:15, No:1, 154-160.

Schwarzer, Steve, (2011) "Political Socialization As The Driving Fact Or For Political Engagement And Political Participation", Advanced Techniques for Political Communication Research: Content Analysis“, p.1-12, March 20-24, 2011, Amsterdam.

Smith, Anthony D, (1999) Milli Kimlik, (Çev. Bahadır Sina Şener), İletişim Yayınları, İstanbul.

Sözen, Edibe, (1999) Demir Kafesten Plastiğe Kimliklerimiz Sekülerleşme Sürecinde Kimliklerin İnşası, Birey Yayıncılık, İstanbul.

Tok, Nazif, (2003) Kültür, Kimlik ve Siyaset, Ayrıntı Yayınları, İstanbul.

Türkkahraman Mimar (2000) Türkiye'de Siyasal Sosyalleşme ve Siyasal Sembolizm, Birey Yayıncılık, İstanbul.

Uysal, Birkan, (1981) “Siyasal Katılma ve Katılma Davranışı Üzerinde Ailenin Etkisi”, TODAİ Amme İdaresi Dergisi, Vadi Yayınları, 55-72.

Yegen, Ceren, (2018) Siyasal İletişim, Propaganda ve Ulusal Kimlik, Kriter Yayınları, İstanbul. 